\title{
İkinci Dünya Savaşında İsmet İnönü ve Churchill Arasında Yapılan Adana Görüş̧mesi
}

\author{
Dr. Osman YALÇIN*
}

\begin{abstract}
$\ddot{O}_{z e t}$
I'inci Dünya Savaşının Sonuçları 2'nci Dünya Savaşının da nedenidir. Savaş 01 Eylül 1939 günü sabahın erken saatlerinde, bir radyonun Polonyalılar tarafindan basıldı $\breve{g}$ haberi ile Almanların hızla Polonya sinırlarına girişi ve bu gelişme üzerine Sovyet ordularının da Polonya'nın doğu sinırından girmesi ile başlamışıtır.

1939 yllında başlayan 2'nci Dünya Savaşı 6 yll süresince taraf olmayanları da daima meşgul etmiştir. Taraf olmamasına rağmen taraflar kadar harbin sıkıntısını yaşayan en şanssız ülke hiç şüphesiz Türkiye olmuştur. Türkiye harbin ayak seslerini daha 1930'ların ilk ylllarında anladığndan yakın gelecekte büyük bir harbin içerisinde kalarak genç cumhuriyetin heba edilmemesi, milletin yeni sıkıntılara düçar olmaması için bölgesinde ittifaklar yapmıştır.

Ingiliz Başbakanı Churchill, Roosvelt'e; Türkiye'nin bir üs haline getirilerek Akdeniz'de Türk savunmasını hazırlamaya ikna için gayret etmiştir. Churchill, Kazablanka görüşmelerinden sonra Türkiye'yi saflarında harbe sokabilmek için 30 Ocak 1943 tarihinde Türkiye'ye gelmiş ve Adana'da İsmet Inönü ile bir görüşme yapmışıtrr. Görüşmeler 2 gün sürmüştür.

Bu görüşmelere "Sağırlar Diyaloğu” da denmektedir. Çünkü Churchill ve İönü taban tabana zıt fikirlerde görüşmelere katılmışlar, görüş̧e sonunda her iki taraf amacına ulaştığı izlenimi ile ayrılmıştır. Görüşme dünya basınında ve iç basında büyük yank yapmıştır. Türkiye, karşılanması imkansız şartlar ile Ingiltere'yi oyalamıştır. Bulunduğu konum itibariyle tarafsı kalmasının daha yararlı olacağı politikasl, 1945 yılı Şubat ayına kadar korunmuştur. Bu tarihte ise kazanan tarafin belli olmastyla yeni kurulacak Birleşmiş Milletlerde yer alabilmek için Almanya ve Japonya 'ya göstermelik savaş açılmıştır.
\end{abstract}

\footnotetext{
*HHO Öğretim Görevlisi, o.yalcin@hvkk.tsk.tr
} 


\title{
Adana Meeting Between Churchill and İnönü during the Second World War
}

\begin{abstract}
Abstarct
Results of 1st World War are also the reasons of 2 nd World war. The War started in the early morning of September the 1st in 1939 where Germans passed the Polish border, with the news of an unexpected attack to a radio station, while Soviets also entered Poland from the east.

The Second World War troubled both the involved nations and the others as well in 6 years. Inspite of being involved, the unluckiest country which had serious effects of war, was Turkey. When Turkey found out the battlecries of the upcoming war, in order to save the young republic, made new allies for the sake of country and its people.

Britain's Prime Minister Churchill, tried to convince Roosvelt for making Turkey a base for defendin Mediterranean. After Casablanca meeting, Churchill came to Turkey/ADANA in order to convince Turkey to fight for their side and met with Inönü. Meetings lasted for 2 days.

This meeting is also called "Dialogue of the Deaf" because they were completely opposite to each other and they left the meeting with the idea of victory. It was a remarkable event both domestic and foreign press. Turkey detained England with impossible conditions. Turkey remained neutral untill February 1945 and after that, when the winning side appears, in order to be in the newly established United Nations, declared nonfunctional war to Germany and Japan.
\end{abstract}

\section{GIRIŞ}

1914 yılında başlayan Birinci Dünya Savaşı 1918 yılına kadar sürmüş ve sonuçları itibariyle insanlığın o tarihe kadar yaşadığı en büyük yıkım olmuştur. Rakamlar kaynaklarda farklı geçmekle birlikte 3,5 milyonu Türk, yaklaşık 30 milyon insan savaşta hayatını kaybetmiştir. Amerika, 1917 yılında taze ve dinç kuvvetlerle savaşa girmiş ve savaşın sonucunu belirleyici bir güç olarak belirmiștir ${ }^{1}$. 1918 yılından 1939 yılına kadar geçen 21 yıl yeni bir savaşa hazırlık dönemi olarak geçmiştir. 1'inci Dünya Harbi'nden sonra Osmanlı Devleti tasfiye edilirken, Ankara'da kurulan yeni Türk devleti bir taraftan emperyalizme karşı mücadele ederken, diğer taraftan Batı dünyasının içinde olmayı da milli bir politika olarak

\footnotetext{
${ }^{1}$ Eric Hobsbawn, (Çev.Yavuz ALOGAN), Kısa 20. Yüzyıl 1914-1991 Aşırılıklar Çağı, Everest Yay.,İstanbul, 2006, s.30
} 
benimsemiştir². Türkiye'nin idarecileri, harbin ayak seslerini 1930'ların ilk yıllarında duymuştur. Bu olumsuz gelişmeler zamanında, 1911-1922 yılları arasında yaşanılan sıkıntıların bir daha yaşanmaması için bir takım ittifaklar yapılmıştır.

\subsection{Türkiye'nin İttifak Girişimleri ve Savaşın Başlaması}

Atatürk, 2'nci Dünya Savaşı'ndan çok önce Avrupa'daki olumsuz gelişmeleri sezmiş ve bunu açık olarak ifade etmiştir. 1931 yılında Amerikalı General Mc Arthura; "Versailles Muahedesi, Birinci Dünya Savaşı'na sebebiyet vermiş olan amillerden hiçbirini ortadan kaldırmamıştır. Tersine olarak, dünün başlıca rakipleri arasındaki uçurumu büsbütün derinleştirmiştir. ...."der. Atatürk'e göre bu muhtemel savaşın galibi; Fransa, İngiltere ve Almanya olmayacaktır. Savaşın galibi Bolşevizm'dir. Bunun gerekçesi olarak da Bolşeviklerin geri kalmış doğu halkının milli duygularını tahrik etmesidir ${ }^{3}$.

Yayılma emelleri olan İtalya, Mussollini döneminde hızla silahlanmış, Akdenize sınır olan devletler için önemli bir tehdit olmuştur. İtalya bu hali ile Türkiye için de önemli bir tehdit unsuru olmuştur ${ }^{4}$. Atatürk bu gelişmeler karşısında başta hava kuvvetlerinin güçlendirilmesi, bölgede gövde gösterisi gibi bazı tedbirler almıştır. Bu gelişmelerin olduğu bir zamanda, Sovyetler Birliği ise Almanya ile saldırmazlık anlaşması imzalamışıır ${ }^{5}$. Türkiye, İran, Irak ve Afganistan arasında 08 Temmuz 1937'de Tahran'da Sadabad Paktı imzalanmış, Türkiye'nin girişimciliği ile yapılan bu pakt ile bölgede yapılacak yöresel kalkışma ve dış tahriklere karşı güç birliği sağlanmıştır.

Türkiye İki dünya savaşı arasında geçen yıllarda; nüfus mübadelesini gerçekleştirmiş, 1936 Montreux Boğazlar Sözleşmesi ile Türk Boğazlarının üzerinde Türk egemenliği sağlanmıştır. Ancak Sovyetler Birliği 1936 Montreux Boğazlar Sözleşmesinden rahatsızlığını zaman zaman savaş

\footnotetext{
${ }^{2}$ CEBECİĞLU, “İkinci Dünya Savaşı ve Türk Silahlı Kuvvetleri”, 6'ncı Askeri Tarih Semineri I, İkinci Dünya Savaşı ve Türkiye 20-22 Ekim 1997-İstanbul, Gnkur.Bsm., Ankara, 1998, s.324-326

${ }^{3}$ KORBEK,a.g.m., s.83,84; İbrahim ARTUÇ, İkinci Dünya Savaşı 1. Cilt, Kastaş Yayınevi, İstanbul, 2003, s.173

${ }^{4}$ Durmuş YALÇIN-Cemal Avc1, Türkiye Cumhuriyeti Tarihi II, Atatürk Araştırma Merkezi, Ankara, 2002, s. 448 Atatürk, İtalya'nın bu tavrı karşısında Akdeniz'de tatbikatlar yaptırır. Türkiye'nin kararlılı̆̆ını açık olarak gösterir. Özellikle Türk Hava Kuvvetlerini güçlendirmek için Türkiye'den kalkıp Roma'yı bombalayacak uçak arayışına girilir. Nitekim dönemin en gözde uçağı olan ama değeri Türkiye'nin tedarik etmesi ile anlaşlan MARTIN139 Uçağı alınır. Bu duruma başta İtalya olmak üzere sert tepki gösterilir.Hulusi KAYMAKLI, TÜRK Havacılık Tarihinde Türkler 2, Hv.Bsm., Ankara, 1997, s.224

${ }^{5}$ CEBECİĞLU, a.g.m.,s.326
} 
yıllarında dile getirmiştir ${ }^{6}$. Hatay sorunu, Atatürk'ün sağlığında çözülmüş ve yalnızca anavatana katılma süreci kalmıştır ${ }^{7}$.

Almanlar, Polonya'yı istilaya başladığı zaman Türkiye'nin tarafsız kalmasının önemli bir güvencesi, Sovyetler Birliği ile ilk defa 1925 yılında yapılan Dostluk ve Saldırmazlık Anlaşması'ydı'. Balkan Antantı, Montreux Sözleşmesi ve Sadabad Antlaşması ile Türkiye'nin uyguladığı aktif politika, Sovyetler ile mevcut olan sıkı ilişkilerin zayıflamaya başlamasına neden olmuştur. Türkiye'nin güvenlik endişesi ile yaptığ 1 diğer önemli bir girişim ise 19 Ekim 1939 tarihinde Türk-İngiliz-Fransız Anlaşması (Ankara Anlaşması) olmuştur ${ }^{9}$. Türkiye muhtemel savaşın taraftarları olarak görülen büyük devletlerle anlaşmalar yapmıştır. Bu maksatla;.19 Ekim 1939 tarihinde Türk-İngiliz-Fransız Anlaşması (Ankara Anlaşması), 25 Mart 1941 Türkiye-Sovyetler Birliği arasında karşılıklı güven deklarasyonunun yayınlanması, 28 Şubat 1941, 12 Mayıs 1941, 23 Mayıs 1941 de Almanya'nın lideri Hitler'in İnönü'ye 2 defa güvence mektubu göndermesi ve Almanya'nın Türkiye ile anlaşma gayreti sonucunda, Türkiye ile Almanya arasında 18 Haziran 1941 Türk-Alman Saldırmazlık Anlaşması imzalanmıştır ${ }^{10}$.

Almanya 1939-1942 yılları arasında Mihver Kanadına katılması için Türkiye'ye baskı yapmıştır. Bu sürede Türkiye'ye yönelik bir takım belirsiz gelişmeler olmuştur. 1941-1942 yıllarında Türk-Sovyet sınırında sıklıkla yabancı uçaklar uçmuştur. Bu konuda Türk dışişleri Almanlar ile görüşmede bulunarak bahse konu uçakların kendilerine ait olup olmadığını sormuş, Almanlar kendilerine ait böyle bir uçuş ihlalinin olmadığını ancak Sovyetlerin ele geçirdiği Alman Messerschmidtt-109-110 ile Junkers-87 tipi uçaklarında tadilat yapıp Alman işaretleri ile kullandıkları ve bu şekilde Türkiye'nin, Almanya ile arasını açmayı amaçladıkları cevabını vermişlerdir $^{11}$. Almanların Türkiye'ye yönelik tehditleri harp süresince aralıklarla devam etmiştir. 4 Aralık 1943 tarihinde bir Türk motorunun,

\footnotetext{
6 SSCB, İkinci Dünya Savaşı yıllarında Türkiye'ye, Alman gemilerinin boğazlardan geçmemesi konusunda nota vermiştir. Savaş sonrası ise bu durum bir kriz olarak 1953 yılına kadar devam etmiştir.

${ }^{7}$ CEBECIOĞLUU, a.g.m., s.325

${ }^{8}$ YALÇIN-AVCI, a.g.e., s. 460

${ }^{9}$ İsmail KURTCEBE,'İkinci Dünya Savaşı Sonunda Türkiye Üzerinde Rus Baskısı", 6'ncı Askeri Tarih Semineri I,İkinci Dünya Savaşı ve Türkiye 20-22 Ekim 1997-İstanbul, Gnkur.Bsm., Ankara, 1998,s.127-129

${ }^{10}$ ATASE Bşk.lığı, "İkinci Dünya Savaşı Kronolojisi”, Altıncı Askeri Tarih Semineri Bildirileri II İkinci Dünya Harbi ve Türkiye 20-22 Ekim 1997-İstanbul, Gnkur.Bsm., Ankara,1999, s.440-469; YALÇIN-AVCI, a.g.e., s. 451-453

${ }^{11}$ BCA,T.C. Hariciye Vekaleti, 11 Haziran 1942, 030. 10, 232, 562, 11
} 
Bodrum açıklarında batırıldığı Muğla Valiliği tarafından rapor edilmiştir ${ }^{12}$. Yine 1944 yılının ilk günlerinde Alman uçakları Marmaris sahilinde pike yaparak makineli tüfek atışı yapmışlar ve bomba atmışlardır ${ }^{13}$. Savaş yıllarında değişik ülkelerden 100 civarında uçak ve 300 civarında mürettebat Türkiye'ye inmiştir.Mürettebattan bir kısmı kaza sonucu hayatını kaybederken, çok az bir kısmı kaçmayı başarabilmiştir. Konu ile ilgili Arşiv belgelerinde inen uçakların analizi verilmektedir ${ }^{14}$. Diğer taraftan 23 Ağustos 1939 'da Sovyetler Birliği ile Almanya arasında Saldırmazlık Paktı imzalanması, en çok Türkiye'yi şaşırtmıştır ${ }^{15}$.

01 Eylül 1939 günü Almanya'nın Polonya'ya taarruzuyla başlayan, yaklaşık 40-60 milyon kişinin ölümü ile sonuçlanan 2'nci Dünya Savaşı kısa sürede yayılmış ve tüm dünyayı etkisi altına almıştır ${ }^{16}$.

\section{2. İkinci Dünya Savaşının İlk yıllarında Türkiye}

Atatürk'ün 10 Kasım 1938'de vefatı ile Türkiye‘de "Milli Şef” dönemi olarak adlandırılan İsmet İnönü dönemi başlamıştır. Bu dönemde; Başvekil Refik Saydam, Dışişleri Bakanı Şükrü Saraçoğlu ve Dışişlerinde önemli bir diğer kişi ise Numan Menemencioğlu'dur ${ }^{17}$. Türkiye'nin, 2'nci Dünya Savaşı'nda takip ettiği temel politika, Mihver ve Müttefik devletlerin Türkiye'yi kendi taraflarına çekmek için yaptıkları baskı politikasını uzlaşı ile atlatma çabası olmuştur ${ }^{18}$. Savaşın başlaması ile iç ve dış ticaret durgunlaşmış, Türkiye'nin ekonomik sorunları büyümüş, üretim düşmüştür. Üretici kesimin silah altına alınması bu durumda etkili olmuştur.

İsmet İnönü, 2'nci Dünya Savaşı'nda Cumhurbaşkanı olarak dış politikada tek belirleyici olmuştur. İsmet İnönü, İkinci Dünya Savaş'nda Türkiye'nin aktif tarafsızlık üzerine bir politika takibini benimsemiştir. Türk ordusu savaşın hızla gelişmesi ile seferberlik durumuna geçmiştir. Savaşın başından itibaren İnönü, dış gelişmeler karşısında aceleci olmamış ve

${ }^{12}$ BCA,T.C. Dahiliye Vekaleti ve Muğla Valiliği, 5 Aralık 1943, 030. 10, 232,563, 9

${ }^{13}$ BCA,T.C. Dahiliye Vekaleti ve Muğla Valiliği, 13 Ocak 1944, 030. 10, 232,563,13

${ }^{14}$ BCA, 030-0-010-000-000-59-402-30 Genelkurmay Arşiv Belgesi

${ }^{15}$ YALÇIN-AVCI, a.g.e., s. 450

16 Mehmet Ali YALÇIN (Der.), İkinci Dünya Savaşının Gizli Belgeleri, MAY Yay.,İstanbul, 1968, s.155; Rifat UÇAROL, "İkinci Dünya Savaş1 "Misak-1 Milli" ve Türkiye'nin Savaşa Girmemek için Direnişı”, Altıncı Askeri Tarih Semineri Bildirileri II İkinci Dünya Harbi ve Türkiye 20-22 Ekim 1997-İstanbul, Gnkur.Bsm., Ankara, 1999, s.525

${ }^{17}$ GÜRÜN, a.g.m.s.s.12

18 Ergun KORBEK, "2 nci Dünya Savaşında İngiltere Başbakanı Winston Churchill ile Cumhurbaşkanı İsmet İnönü Arasındaki Adana Görüşmesi, (30-31 Ocak 1943)”, 6'ncı Askeri Tarih Semineri I, İkinci Dünya Savaşı ve Türkiye 20-22 Ekim 1997-İstanbul, Gnkur.Bsm., Ankara, 1998, s.81 
Türkiye'yi bağlayıcı kararlar alınmamıştır. Mihver Devletler ile İttifak Devletlerinin Türkiye'yi savaşa dahil etme baskısına karşı zaman kazanmaya çalışmış ve muhataplarını oyalamayı başarmıştır.

Türkiye'ye göre savaş sonunda Avrupa'nın bolşevikleştirilmesi kaçınılmazdır ${ }^{19}$. Türk tarafi, sonucu belli olmayan bu savaşta, "bekle-gör" politikası ile tarafları oyalamak üzerine bir dış politika geliştirmiş ve çizgisini korumuştur. Türkiye'yi savaşa sokma gayretlerine karşı baskılara direnilmiş, ülkenin egemenlik hakkı korunmuştur ${ }^{20}$. Zaman zaman basından ve savaşan devletlerden oldukça fazla eleştiri alan bu politikanın genel olarak Türkiye bakımından başarılı olduğu değerlendirilmektedir.

\subsection{Müttefiklerin Türkiye Üzerinde Baskı Politikası}

Türkiye, Montreux Boğazlar Sözleşmesi sonrası İngilizlere daha yakın davranmayı ulusal çıkarları bakımından faydalı görmüştür. Diğer ülkelerle ilişkilerde Türkiye'nin temel ilkesi; münasebetlerin karş1lıklı egemenlik, eşitlik ve ülke bütünlügüne zarar vermeden sürdürülmesi olmuştur ${ }^{21}$. Almanya; Fransa ve İngiltere'nin Türkiye'yi, “Barış Cephesi” içine alma müzakeresinden rahatsız olmuştur. Almanya, Türkiye'nin İtalya'dan duyduğu endişeyi gidermek için deneyimli dışişleri görevlisi Von Papen'i Ankara'ya elçi olarak atamıştır. Von Papen'in görevi, Türkiye'yi Almanya'ya yakın tutmak ve mümkün olması halinde İngiltere ile bir ittifaka girmemesini sağlamak olarak belirtilmiştir ${ }^{22}$.

22 Haziran 1941'de Almanya'nın Rusya'ya saldırısı ile savaş, Türkiye'nin en önemli gündemi haline gelmiştir. Türkiye gelişmeler karşısında büyük endişe duymuş ve her iki ülkeye tarafsızlığını bildirmiştir. 1'inci Dünya Savaşındaki gizli antlaşmalar gibi bir oluşumun Rusya ile İngiltere arasında da olma ihtimali, Türk idarecileri tarafından gözardı edilmemekteydi. Türkiye'de aynı gün aldığı karar ile silahlı tarafsızlığını ortaya koymuştur ${ }^{23} .7$ Aralık 1941'de ABD'nin savaşa dahil olması, savaşı mihver devletlerin kaybedeceği tezini güçlendirmiştir. 1942 yılında savaş daha da yoğunlaşmıştır. Türkiye, taraflardan birinin saldırısına uğramamak ve savaşa girmemek için aktif tarafsızlığını sürdürmekte kararlılığını göstermeye önem vermekte, diğer taraftan ise olası bir saldırıya karşı da hazırlıksız yakalanmamak için askeri tedbirlere ağırlık vermekteydi. Ülkenin

${ }^{19}$ YALÇIN (Der.), a.g.e., s.155, s.50-55

${ }^{20}$ KORBEK,a.g.m., s.84-86

${ }^{21}$ Mehmet GÖNLÜBOL, Uluslar arası Politika, Ankara Ünv.Bsm., Ankara, 1978, s.45-50

${ }^{22}$ KORBEK,a.g.m., s. 87

${ }^{23}$ BCA, 030-0-018-001-002-95-54-1(Türkiye'nin Alman-Sovyet Harbine Karşı Tarafsızlığı 22.06.1941) 
bir oldu bitti ile her an bir harekat ortamına girilebileceği gözardı edilmemektedir. $\mathrm{Bu}$ dönemde bu maksatla birçok manevra yapılmıştır.

Fransa'nın hazırlıksız bir şekilde savaşın tarafı olması ve teslimi, savaşın yayılması ile Türkiye'nin tarafsız kalması, İngiltere için daha da önemli hale gelmiştir. Türkiye'nin tarafsız ülke olarak durumu 1942 yılında başka bir gelişme ile bir defa da Almanların lehine bir durum oluşturur. Müttefiklerin Almanya'ya planladıkları saldırıda, Alman Cephesine karşı Türkiye arada bir engel olarak saldırı planlarını olumsuz etkilemektedir. Alman ilerleyişi karşısında set olan Türkiye'nin tavrından memnun olan Müttefikler, şartlar lehlerine dönmeye başladığında Türkiye engelinden rahatsızlık duymaya başlamışlardır. Bu nedenle İngiliz Başbakanı Wınston Churchill, 1943 başında Türkiye'yi savaşa sokmak için yoğun bir diplomasi mücadelesi vermiş ve tarihte Adana Görüşmeleri olarak yerini alan zirve için Türkiye'ye gelmiştir. Adana Görüşmeleri uzun süre Türkiye ve dünya kamuoyunda yer almıştır.

\section{Adana Görüşmeleri (30-31 Ocak 1943)}

1943 yılı 2’nci Dünya Savaşının en kritik yılı olmuştur. 1943 yılında Mihver Devletleri savunmaya geçmek zorunda kalırken, müttefikler ise taarruza yönelmeye başlamıştır. Ancak mihver devletlerinin mevcut gücü, Türkiye için hala tehdit boyutundadır. Başkan Roosevelt ile İngiliz Başbakanı Churchill, 12-24 Ocak 1943 tarihinde Kazablanka'da bir araya gelerek savaş ile ilgili bir konferans düzenlemişlerdir ${ }^{24}$. İngiliz Başbakanı Churchill, Roosevelt'i ikna ederek; Türkiye'nin bir üs haline getirilmesini ve Akdeniz'de Türk savunmasının oluşturulmasına ikna için gayret etmiş ancak Amerikalı askeri danışman Marshall bu duruma karşı çıkmıştır.

$\mathrm{Bu}$ görüşmelerde ABD Başkanı, Türkiye'nin Savaşa dahil olmasına ikna edilmiştir. Konferansın son günü Roosevelt'in, Almanya ile ancak kayıtsız şartsız teslimi halinde görüşebileceğini açıklaması, Türkiye'yi endişeye sevk etmiştir. Çünkü, bu durum gerçekleşirse Sovyetlerin, Avrupa'nın en büyük gücü olarak ortaya çıkması söz konusudur. Sovyetlerin büyük bir güç olması ise, Türkiye için önemli bir tehdit anlamına gelmektedir. Türk devlet adamlarına göre, Sovyetlerin Türkiye üzerinde baskı kurması ve Türk Boğazları üzerinde söz sahibi olmak için harekete geçmesi öngörülmektedir. Churchill bu kozu kullanarak Türkiye'yi harbe sokmak istemektedir ${ }^{25}$. Türk devlet adamları ise bu gerçeği görerek Türkiye'yi harbin taraftarı yapmamaya çalışmışlardır. Diğer taraftan ise

\footnotetext{
${ }^{24}$ KORBEK, a.g.m., s.89

${ }^{25}$ KORBEK, a.g.m., s.89; William Hale, a.g.e.,s.90-93
} 
İngiltere ile de ilişkileri bozmamak, Türkiye'nin takip ettiği dış politika bakımından önemlidir.

Alman ordularının 1942 yılında Stalingrad Savaşı'nı kaybetmesi sonucu Almanların Türkiye üzerindeki baskısı önemli ölçüde kalkmıștır. Bu tarihten sonra ise Türkiye üzerinde müttefiklerin baskısı başlamıştır ${ }^{26}$. Müttefiklerin stratejisine göre; Almanların kesin yenilgiye uğratılmaları için Balkanlara yönelik kesin sonuçlu bir harekat yapılması gerekmektedir. Bu hareketin anahtar1, Churchill'in tabiriyle Türkiye'dir. Müttefikler 1943 yılını Almanları yenilgiye uğratacak planları yapmak ve uygulamak için yoğun çalışmalar yapmakla geçirmiştir. Churchill, Ortadoğu ile Balkanlar arasında bulunan Türkiye'nin savaşa girmesi ile neticenin hemen alınacağını hesaplamaktadır ${ }^{27}$. Oysa Amerika yönetimi ile İngiliz Genelkurmay1, Churchill ile aynı kanaatte değildir. Türk ordusunun mevcut haliyle, donanımının demode ve yetersizliği nedeniyle müttefiklere istenilen faydayı vermesi olas1 görünmemektedir. Bu görüşe göre müttefikler Türkiye'nin topraklarından yararlanmalı ve buradan Romanya petrollerinin bombalanması sağlanmalıydı. Bu kapsamda 26 Kasım 1942'de Türkiye'den, Türk Boğazlarının açılması talep edilmiştir. Bu talebe Amerika da destek vermiştir.

Müttefikler, Romen petrollerinin bombalanması için Türkiye'ye yönelik planlarından 24 Kasım 1942'de Stalin'i de haberdar etmişler ve gerekçesini bildirmişler. Stalin, 27 Kasım 1942'de verdiği cevapta müttefiklerin görüşüne katıldığını bildirmiştir ${ }^{28}$. Kazablanka Görüşmelerine kadar başka bir gelişme olmamıştır. Alman baskısını kıran ve ordusunu daha da güçlü hale getiren Stalin, 1942 yılından itibaren daha özgün bir politika izlemeye başlamıştır.

Churchill'in; Yunanistan, Oniki Ada, Balkan Planı ile Türkiye'nin harbe ortak edilmesi, Başkan Roosevelt tarafindan kabul görmemiştir. Ancak Roosevelt, Türkiye ile olan girişimleri askeri alanda kalmak kaydıyla İngiltere'nin koordine etmesinin teyidini vermiştir. Bu teyit üzerine Churchill, Kazablanka Görüşmelerinden sonra Adana’ya gelmiştir.

Churchill, Kazablanka Görüşmelerinden sonra Türkiye'yi saflarında harbe sokabilmek için 30 Ocak 1943 tarihinde Türkiye'ye gelmiş ve

26 İzzet ÖZTOPRAK, "İkinci Dünya Savaşı Döneminde Adana Görüşmelerinin Askeri Yönü”, Altıncı Askeri Tarih Semineri Bildirileri I İkinci Dünya Harbi ve Türkiye 20-22

Ekim 1997-İstanbul, Gnkur.Bsm., Ankara,1998, s.182

${ }_{27}$ İbrahim ARTUÇ, İkinci Dünya Savaşı 2. Cilt, Kastaş Yayınevi, İstanbul,2003, s.40,41

${ }^{28}$ ÖZTOPRAK, a.g.m., s.182; T.C. Dışişleri Bakanlığı, a.g.m., s.134,137 
Adana'da İsmet İnönü ile iki gün süren bir dizi görüşmeler yapılmıştır ${ }^{29}$. Churchill, 30 Ocak 1943'de 14:20'de Adana'ya gelmiştir. Dönemin Cumhurbaşkanı İsmet İnönü (1938-1950), 16:10‘da İngiliz Başbakanını Adana'da bir trende kabul etmiştir.

Görüşmelere İsmet İnönü'nün yanında; Başbakan Şükrü Saraçoğlu, Genelkurmay Başkanı Mareşal Fevzi Çakmak, Dışişleri Bakanı Numan Menemencioğlu, Ortaelçi Feridun Erkin, Genelkurmay Hava Müşaviri Hv.Plt.Tuğg. Şefik Çakmak, Gnkur.Hrk.Ş.Md. Albay Fasih Kayabalı katılırlar $^{30}$. M.Winston Churchill görüşmelere siyasi ve İngiliz Genelkurmay Başkanı olmak üzere en üst askeri erkanın da dahil olduğu kalabalık bir heyetle katılmıştır ${ }^{31}$. Bu görüşmelere "Sağırlar Diyaloğu” da denmektedir. Bunun nedeni, Churchill ve İnönü'nün taban tabana zit fikirlerle görüşmelere katılması, ve görüşme sonunda her iki tarafın amacına ulaşttğı izlenimi ile ayrılmasıdır. Oysa daha sonra ortaya çıkan tablo özellikle M.Winston Churchill'in istediğini alamadığı gerçeğini göstermiştir.

Görüşmelerin nerede yapılacağı konusu ayrı bir sorun olmuştur. İnönü-Churchill Görüşmesinden kısa bir süre önce Alman Büyükelçi Von Papen'e Ankara'da suikast düzenlendiğinden, görüşmenin Kıbrıs'ta yapılması veya ülke içerisinde bir trende yapılması planlanır. Daha sonra Adana'da gizli olarak bir trende yapılması için Churchill ile mutabık kalınmıştır ${ }^{32}$. Churchill, bu görüşmeleri üç aşamalı bir plan dahilinde hayata geçirmeyi öngörmektedir. Bunlar;

a. Türk ordusunun modern silahlarla teçhiz edilmesi,

b. Türk topraklarından ve üslerinden müttefiklerin yararlanması,

c. Türkiye'nin müttefikler safında savaşa katılmasıdır.

Churchill'in tezine göre; İtalya'ya karşı topyekün bir savaş başlatılmalıdır. Bilindiği gibi bu dönemde Balkanlar Almanların, Adalar denizi İtalya'nın elindedir. Suriye, Irak ve Kıbrıs'ta ise İngilizler bulunmaktadır. Türkiye müttefikler ile Mihver Devletleri arasından geniş bir toprak parçası ile set durumdayd. Churchill'e göre; İtalya açılacak geniş kapsamlı bir saldırı ile yenilecek ve savaş dışı kalacaktır. Balkanlarda yalnız kalan Almanya'ya karşı; Kuzeyden Sovyetler Birliği taarruz edecek,

\footnotetext{
${ }^{29}$ YALÇIN-AVCI, a.g.e., s. 456,457

${ }^{30}$ AYIN TARİi், "VESIKALAR", Bas.ve Yay.Md.lügü, Ankara, Şubat 1943, s.110,111; KORBEK, a.g.m., s.89,89. NOT: General Şefik ÇAKMAK, Mareşal Fevzi ÇAKMAK'ın damadı olup, kayınpederine olan sevgisi sebebiyle onun soyadını almıştır.

${ }^{31}$ AYIN TARIHİ, "VESIKALAR", Subat 1943, s.110,111

32 ÖZTOPRAK, a.g.m., s.156-162
} 
müttefiklere Türkiyenin katılması ile güneyden açılacak güçlü bir cephe ile taarruz edilirse, Alman yenilgisi kolaylaşacaktı. Beklenen etkinin alınabilmesi için Romanya petrolleri ateşe verilerek Almanya'nın askeri gücünün hareket kabiliyetine darbe vurulması da planın önemli bir ayrıntısı olarak yer almaktadır ${ }^{33}$. Bu nedenle Türkiye'nin 1943 yılı içinde müttefikler safında savaşa girmesi Churchill için çok önemlidir. Türkiye, Müttefiklere karşı taahhütlerini yerine getirmelidir. İsmet İnönü bu durum karşısında iki husus üzerinde durmuştur.

a. Türkiye, Sovyet Rusya'nın durumundan emin değildir. Almanya'nın yenilmesi ile Sovyet Rusya, Avrupa'da en güçlü devlet olarak, hakim güç olacaktır. Bu durumun ise Türkiye açısından yeni sıkıntılara neden olma ihtimali bulunmaktadır.

b. Türk ordusunun; silah, teçhizat olarak donanımı yetersizdir. Türk ordusunun savaşacak duruma gelmesi için modernizesinin tamamlanması gerekmektedir $^{34}$.

Silah ve techizat olarak Türkiye'nin eksiklikleri ve gerekli olan desteğin yapılması her iki liderin de gündemindedir. Churchill, Türkiye'ye önemli miktarda silah sistemi ve techizat desteği verip Türkiye'yi savaşa sokmayı planlamaktadır. Türk tarafı ise bu desteği gerekli bulmakla birlikte bunun savaşa girmek için yeterli olmayacağını değerlendirmekteydi. Konunun detayları daha sonraki girişimeler, beklenenin aksine Türkiye için avantaja dönüşmüştür.

Toplantıda Şükrü Saraçoğlu görüşünü açıklar ve Churchill'e; "Sovyetlerin, emperyalist olacağını ve anlaşmaların gerçek bir garanti vermeyeceğini” bildirir. Churchill, komünizmin artık değiştiğini, kaldı ki böyle bir durumda kurulacak olan milletlerarası cemiyetin gerekli önlemi alacağını söyler ${ }^{35}$. Savaş sonrası yaşananlar bunun pek öyle olmadığını ve İngiliz Başbakanın yanıldığını doğrulamıştır.

Churchill, Kazablanka'dan büyük ümitlerle Adana'ya gelmiştir. Adana'da Sovyet tehdidi ile Türkiye'yi korkutacakken, Türk heyetinin tehlikeleri çok daha yalın ve açık bir şekilde Churchill'e aktarması, Churchill'in Türk heyetini yatıştırma çabasına dönüşmüştür. Esasen olası bir harpte Türkiye'nin oldukça zayıf olan sanayii kısa sürede büyük zararlara

\footnotetext{
${ }^{33}$ T.C. Dışişleri Bakanlığı, Türkiye Dış Politikasında 50 Yıl İkinci Dünya Savaşı Yılları (1939-1945), Dışişleri Yay., Ankara, 1973, s.VI,VII

${ }^{34}$ KORBEK, a.g.m., s.90; ÖZTOPRAK, a.g.m., s.184; ARTUÇ, İkinci Dünya Savaşı 2. Cilt, Kastaş Yayınevi, İstanbul, 2003, s.42

${ }^{35}$ YALÇIN-AVCI, a.g.e., s. 458, 459
} 
uğrayabilir, özellikle İstanbul'un ahşap yapı ağırlıklı olması nedeniyle büyük zayiat görmesi kaçınılmazdı. Diğer taraftan, Türkiye'nin katılacağı bir savaşta henüz oturmakta olan cumhuriyet rejimi ile misak-i milli sınırlarının tehlikeye girme riski bulunmaktaydı.

Adana Görüssmesinin 2'nci günü olan 31 Ocak 1943 tarihinde daha ziyade askeri tedbirler üzerinde durulmuştur. Gündeme gelen problem sahalar1;

a. Türkiye'nin ihtiyacı olan bir yıllık yedek idame işletme (silah ve techizat) ihtiyacının İngiltere tarafından karşılanması,

b. Türkiye savaşa katılırsa başta İstanbul ve İzmir olmak üzere hava savunmasına İngiltere'nin katkıda bulunması,

c. İngiltere tarafından, Türkiye'nin ihtiyaç duyduğu bazı kara birliklerinin gönderilmesi,

d. Türkiye savaşa girdikten sonra, bağımsız bir hava filosunun Türkiye'de konuşlandırılması,

e. Türkiye'ye, Türk komutası altında olmak üzere İngiliz Tanksavar ve Uçaksavar birliği gönderilmesi,

f. Türkiye'nin ihtiyacı olan silah, teçhizat ve destek sistemlerinin listesinin verilmesi ve bunların İngilizler tarafından karşılanması olarak kararlaştırılmıştır.

Toplantıya katılan Genelkurmay Başkanı Mareşal Fevzi Çakmak ve Genelkurmay Hava Müşaviri Hava Pilot Tuğgeneral Şefik Çakmak ${ }^{36}$; askeri problem sahası olarak tespit edilen hususların daha da anlaşılır ve Türkiye'nin menfaatine uygun şekilde tanımlanması için yoğun çaba göstermiş̧lerdir. Bu görüşmede, Türk ordusunun güçlendirilmesi konusunda problemler tartışılmış ve İngiliz Heyeti'nin aşırı talepleri sınırlandırılmıştır. General Alan Brooke'nin; "Türkiye'ye önemli bir yardım yapamadık. Bu husus şimdiden sonra daha da önemlidir. Her halde Türkiye'yi takviye etmek ve iyi bir duruma getirmek isteriz." ifadesi Mareşal Çakmak tarafından memnuniyetle karşıllanmıştır ${ }^{37}$.

36 NOT: Tuğgeneral Şefik ÇAKMAK, Mareşal Fevzi ÇAKMAK’ın damadıdır. Bu görüşmelerde, Hava Müşaviri görevindedir.

${ }^{37}$ CEBECİOĞLU, a.g.m., s.357, 358 
Türk Komuta Heyetinin görüşü beş hususta toplanmıştır ${ }^{38}$. Bunlar;

a. Cephede kullanılacak silah sistemlerinin (top,tank,füze,silah,vd.) karşılanmas1,

b. Her türlü motorlu araçların temini,

c. Lokomatif, kömür, benzin temini,

d. Demir yollarının yetersizliği nedeniyle gerekli gemi ihtiyacının karşılanması,

e. Hava kuvvetlerinin ihtiyaç duyduğu yeterli uçak ve techizatın verilmesidir.

Toplantıda Alman ve İtalyanlardan alınan savaş ganimetlerinden Türkiye'ye verileceklerin listesinin ihtiyaç listesine eklenmesi kararlaştırılmıştır. Askeri malzeme ile silahların kullanılabilmesi için gerekli eğitimlerin verilmesi hususu da görüşmelerde yer almış ve karşıllılı personel görevlendirilmesi konusunda mutabık kalınmıştır.

Görüşme zabitlarına ilaveten üç ek konmuştur. Bu ekler; askeri hareketlilik için lüzumlu olan alt yapı ile teşkilata dair ihtiyaçlar ile askeri alana dair yapılması gerekli işler, savaş sonrası güvenlik üzerine yapılması gerekenler ve diğer hususları içeren 3'üncü ektir ${ }^{39}$.

Görüşmelerde askeri yardım en önemli sorunlu saha olarak tartışılmış, İngilizler yeteri kadar askeri malzeme desteği verecek güce sahip olmakla birlikte, Türkiye'nin ihtiyacının kısa sürede karşılanması ise mevcut kara, demiryolu ve deniz ulaşım imkanları ile mümkün değildi. Görüşmelerin en can alıcı pürüzü aslında yardımların nasıl ve hangi metot ile Türk ordusuna teslim edileceği konusu olmuştur.

Churchill görüşmelerde Türkiye'yi direk baskı altına alacak bir tavır sergilememiş ancak Sovyet tehlikesini gündeme getirerek, Türkiye'yi müttefikler safinda savaşa girmesi için telkinde bulunmuştur. İngiliz Başbakanın bu tutumu Türkiye'yi rahatlatmış, İngiliz Genelkurmay Başkanı ihtiyaç dışında İtalyanlardan alınan malzemelerden verebileceklerini söylemiştir. Bu aslında Türkiye'ye zaman kazandıran bir başka gelişme olmuş ve Türk heyeti bunu ayrıca değerlendirmiştir. Mareşal Fevzi Çakmak'ın İtalyan malzemelerinin sevkini uygun görmesi ile Türkiye için ilave bir zaman kazanma imkanı kazanılmıştır. Görüşmeler sonrası oluşan karar altı maddede toplanmıştır. Bunlar;

${ }^{38}$ ÖZTOPRAK, a.g.m.,s.184,185

${ }^{39}$ ÖZTOPRAK, a.g.m.,s.186-189 
a. Aciliyet durumuna göre Türkiye'nin ihtiyaç listesi (Kara, Deniz ve Hava Kuvvetlerini kapsayacak şekilde) ile bu listede halihazırda talep edilen, ele geçmeyen malzemeler ile yeni talep edilenler bildirilecek.

b. Türkiye'ye verilecek Türk bayraklı gemilerle Mısır'dan Türkiye'ye ihtiyaçlar taşınacak, gemilerin tip ve tonajını Türkiye belirleyecek.

c. Türk Askeri gücünün modern harp silah ve araçları ile teçhiz edilmesi için Türk Genelkurmayı bir doküman hazırlayacaktır. İngilizlerin Ortadoğu Genel Karargahı ile koordineli olan bu işler uygulamaya geçecekti. Türklerin eğitimi sağlanacak, Zırhlı ve mekanize kuvvetler ile özel bölümlerde Türk Askeri yetkilileri istihdam edilecek, bu hususların detaylarının Türk Genelkurmayı ile İngiliz Servis Ataşeleri arasında bütün detayları ile değerlendirilmesi ve incelenmesi,

d. Hazırlanan ve düzene giren planın taraflarca günden güne takip edilmesi,

e. Türk Hava Kuvvetleri'nin takviyesi planı oldukça ilerlediği için İngiliz kurmay subaylarının en kısa sürede Ankara'ya gelerek Türk Genelkurmayı ile ortak plan hazırlamaları,

f. İngiliz hizmet subayları, Türk Genelkurmayı ile iş birliği yaparak Türkiye'nin savaşa girmesi halinde, verilecek yardım için başta nakil vasıtaları ve imkanları olmak üzere bir plan hazırlayacaklar ve bu planda verilecek yardımın ayrıntısı, içeriği 1943 yılının her ayı için ayrı ayrı yapılacaktır. $\mathrm{Bu}$ maddede Türk ordusunun eksiksiz savaşa girmesi için gerekli; alt yap1, teçhizat, kadro, ilave yeni durumlar ve gerekli olan bütün işlerin değerlendirilmesi öngörülmüştür. İngiliz subaylarının Türk Genelkurmayı ile ortak operasyon planı hazırlamaları da planlanmıştır ${ }^{40}$.

Churchill'in savaşın sürdürülebilirliği ve müttefiklerin kati başarıları için Türkiye'den beklentisi oldukça fazlaydı. Özellikle Türk kara gücünün cephelerde yer almasını ümit etmekteydi. Adana Görüşmelerinden hemen sonra 2 Şubat 1943 tarihli resmi açıklamalar genelgesinde, Türkiye'nin çok kuvvetli bir piyade ordusuna ve techizatına sahip olduğunu söylemiştir ${ }^{41}$.

İngiltere görüşme öncesi ve sonrasında Sovyetler Birliği'nin olumsuz bir yaklaşım içine girmesi ihtimaline karşı, Stalin ile sürekli bilgi alış

\footnotetext{
${ }^{40}$ ÖZTOPRAK, a.g.m.,s.184-188; CEBECİOĞLU, a.g.m., s.355-359

${ }^{41}$ ÖZTOPRAK, a.g.m.,s.189. 1'inci Dünya Savaşı'nda Çanakkale Savaşlarında bu konuda oldukça tecrübe sahibi olduğu anlaşılmaktadır.
} 
verişinde bulunmuştur ${ }^{42}$. Ancak Stalin'in tavrı pek açık olmadığı için İngiltere ve Türkiye, Sovyetlerin alacağ 1 tavırdan endişe etmektedir. Stalin kendisine verilen bilgiler karşısında daha ziyade beklemeyi tercih etmiş, İngiltere'ye rahatsız olmadığını açıklamaktan imtina etmiştir. Türkiye ve İngiltere askeri yardımın Türkiye'nin savunmasını artırmak amaçlı olduğunu ısrarla her platformda vurgulamıştır. Churchill'e göre cesur olan Türk ordusunun teknik alanda eksiklikleri bulunuyordu ve o günkü haliyle Türk Hava Kuvvetleri de zayıf durumdaydı ${ }^{43}$. Adana Görüşmeleri, dünyadaki dengeler bakımından oldukça önemli bir gelişmeydi. Geçen 4 yıl içerisinde Mihver Devletleri ve Müttefikler, Türkiye'yi yanlarında görmek için her türlü girişimde bulunmuşlar, Türkiye ise sınırlarına bir saldırı olmadığ 1 sürece bütün baskılara karşı direnmiştir. Diğer taraftan ise Türk ordusu her an savaşa girecek şekilde bir saldırı karşısında hazır durumdadır. Türkiye, görüşmeleri ustalıkla sürdürmüş, ilişkileri soğutan taraf olmamıştır. Diğer taraftan aktif tarafsız ülke konumunu görüşmeler sonrasında da savaş süresince muhafaza etme iradesini göstermeyi başarmıştır. 30-31 Ocak 1943 tarihleri arasında iki gün süren Adana Görüşmeleri bütün dünyada geniş yankı bulmuş, iç ve dış basında etraflıca tartışılmıştır.

\section{1. İç ve Dış Basında Adana Görüşmeleri}

\section{1) Dış Basında Adana Görüşmeleri}

İngiliz Başbakan Churchill ile Amerika Birleşik Devletleri Başkanı Roosevelt'in Kazablanka Görüşmelerinde Türkiye'nin savaşa girmesi etraflıca tartışılmış ve Roosevelt olaya ilk başlarda sıcak bakmamıştır. Ancak yapılan görüşmeler sonucu ABD Başkanı Roosevelt ikna edilmiştir. Churchill'in büyük bir ümit ve beklenti ile Türkiye'ye gelmesi ve istediğini tam olarak alamaması, Türkiye politikasında başarısızlığı olmuştur. İngiltere, Türkiye'nin savaşa girmemek için topu sürekli taca atmasına rağmen, Türkiye ile olan ilişkilerini devam ettirmekten başka bir seçenek de bulamaz. Savaş koşullarında dünyanın en güçlü devletlerinden biri olan İngiltere'nin politikası, savaşın ortasında kalan ve taraflarca savaşa çekilmek istenen Türkiye ile olan münasebeti dış ve iç basında geniş yankı bulmuştur ${ }^{44}$. Türkİngiliz İlişkilerinin dış basına yansıması ülkeden ülkeye farklılıklar arz etmektedir. Ancak hemen her ülkenin basin gündeminde, Adana Görüşmeleri yer almıştır. Ülkelere ve basın organlarına göre görüşme ile ilgili değerlendirmeleri ülkelere göre aşağıda verilmiştir.

42 T.C. Dışişleri Bakanlığı, a.g.e.,s.136,137; ARTUÇ, İkinci Dünya Savaşı 2. Cilt, Kastaş Yayınevi, İstanbul,2003, s.42,43

${ }^{43}$ William Hale, a.g.e.,s. 79

${ }^{44}$ Korbek, a.g.m., s.92; AYIN TARİHI, “AKISLER, Şubat 1943, s.139 


\section{a) İngiliz Basınında Adana Görüşmeleri}

Anadolu Ajansı'nın Londra'dan bildirdiğine göre İngiliz basını Adana Görüşmelerine oldukça önem vermiștir. Kazablanka Görüșmeleri’nin hemen ardından yapılan bu görüşmeler olumlu bir siyasi adım olarak ele alınır ${ }^{45}$. İngiliz basını, Türkiye'nin savaşın başından beri sergilediği açık ve tarafsız politikasının bir sonucu olarak, gelişmeler hakkında Türkiye aleyhine çok fazla bir yorum yapmaz. Görüşmelerin detayı bilinmediğinden bir sonuç ortaya çıkarılmamıştır. İngiliz basınında etkili olan belli başı gazetelere göre Adana Görüşmelerinin yorumu şöyle olur;

(1) Daily Telegraph; Adana Görüşmeleri bir takım yeni değişikliklere neden olacaktır. Bu bağlamda; Türkiye ihtiyaç duyduğu askeri malzemeleri Britinya'dan alabilecek, ticari bir takım avantajlar sağlayacaktır. Türkiye, Britinya'nın en kötü zamanında dostluğunu göstermiş, Yunanlılara aç kaldıkları bir dönemde gıda desteği vermiştir. Bu görüşmeler Sovyetler tarafindan da olumlu değerlendirilecek ve Sovyetler Türkiye'nin tarafsızlı̆̆ından emin olacaktır.

(2) Daily Mail; Başbakan'ın tarafsız bir ülkeyi hele müttefikliğine sık1 bağlı olan Türkiye'yi ziyareti Kazablanka'dan daha önemlidir. Türkiye, çevresindeki olumsuz gelişmeler ile direkt bağlantılı olması nedeniyle açık, dürüst ve tarafsızlık politikasını başarı ile aşmıştır.

(3) Times Gazetesi; Churchill bu ziyaret ile Afrika Görüşmelerinden en büyük neticeyi almış, sakin, tedbirli, tecrübeli bir asker olan Cumhurbaşkanı İsmet İnönü ile direk temas etme imkanı bulmuştur. Sovyetler de bu ilişkiden memnun kalmış, Türk-İngiliz ilişkilerinin kıymeti teyit edilmiş, Türkiye'nin azimli ve kararlı tavrı anlaşılmıştır.

(4) Manchester Guardian Gazetesi; Görüşme Churchill'in arzusu üzerine gerçekleşmiştir. Türkiye'nin tarafsızlığı kesin olarak anlaşılmış, müttefikler Türkiye'nin genel savunmasını kuvvetlendirmek üzere anlaşmışlardır. Mihver Devletleri tarafından olası bir saldırıda Türkiye'ye yardım konusunda müttefik devletleri mutabık kalmışlardır.

(5) Daily Herald Gazetesi; Görüşme büyük bir olaydır. Bu hadise ile Türkiye tarafsızlı̆̆ını ortaya koymuştur. Türkiye'nin tarafsılılı̆̆ Almanya'nın harekete geçmesini önlediğinden faydalı olmuştur. Türkiye bu görüşme ile müttefiklerin desteğini almıştır.

${ }^{45}$ AYIN TARİHI, “AKİSLER, Şubat 1943,s.139; Korbek, a.g.m., s.92 


\section{b) Amerikan Basınında Adana Görüșmeleri}

Newyork Times'da konu işlenmiştir. Churchill'in ziyaretinin askeri vasfının yanı sıra siyasi vasfı da çok önemlidir. Türkiye, Müttefik ve Mihver devletleri arasında istikrar adasıdır. Savaş hızla müttefikler lehine dönmüştür. Büyük entrikacı Von Papen artık etkisiz kalmıştır. Savaş Almanya aleyhine şekillenmekte ve sindirilmiş ülkeler son zamanlarda tekrar ortaya çıkmaya başlamıştır.

\section{c) Alman Basınında Adana Görüşmeleri}

Alman basını, pek doğal olarak konuya İngiliz ve Amerikan basınına göre farklı bir pencereden bakmıştır. Genel değerlendirme şöyledir; Churchill ile Roosevelt arasında eski samimiyet kalmamıştır. Churchill mevcut halde, Roosevelt'in kararlarının uygulayıcısı durumuna düşmüştür. Churchill, siyasi güç kazanmak için böyle bir girişimde bulunmuştur. Başarılı olursa yeniden etkinlik kazanacaktır. Adana Görüşmeleri, Almanlara karş1 psikolojik harptir.

Alman basını da doğal olarak konuya geniş yer vermiştir. Alman basını bu görüşmeler ile ilgili haberlerinde müttefiklere karş1 psikolojik harp unsurlarını kullanır. Churchill'in girişimi küçük gösterilir, reklam olduğu işlenir. Alman basını Türkiye'nin tarafsızlığına duyulan takdir ve hayranlığa özellikle ortak atıfta bulunur. Türkiye'nin, Almanya ile yaptı̆ğ anlaşmaya bağlı kalacağ 1 , müttefiklere güvenmenin Türkiye için yeterli güvence olamayacağı işlenmiştir. Özellikle Sovyetler Birliği karşısında Türkiye'nin büyük sıkıntıları olduğu gerçeği de işlenmiştir. Alman basını, İngiliz basınının aksine Stalin'in uzlaşma tarafı olmadığını ve her türlü uzlaşmadan uzak durduğuna yer vermiş̧ir.

\section{ç) İtalyan Basınında Adana Görüşmeleri}

İtalyan basınına göre hadise Anglo-Sakson propogandası ve Churchill'in şahsi girişiminin tezahürüdür. Giornale d'italia gazetesine göre Türkiye her ne pahasına olursa olsun tarafsızlığını koruyacak ve müttefiklerin oyununa gelmeyecektir. İngilizler burada da şark memleketlerini kendinden daha büyük taahhütler altına sokmak istemiştir. Gazete, İngilizlerin iddia ettiğinin aksine Stalin, olaya tepkisini izhar etmemiştir yorumunu yapar. İtalyan ve Alman basını aynı perspektifte yorumlar yaparken müttefik ülkelerin basını da doğal olarak kendi politikalarına uygun yorumlarda bulunur. 


\section{d) Macar Basınında Adana Görüşsmeleri}

Yarı Resmi Poster Lloyd Gazetesi görüşmenin Türkiye'nin siyasetini değiştirmediğini, Türk-Alman ilşkilerinin de değişmediğini, Türkiye'nin tavrının harbin ilk yıllarında pek belli olmadığ 1 ve yine bu görüşmeler ile Türkiye açısından bir askeri hareketlilik beklenmediği yorumu yapılmıştır.

Lloyd Gazetesi, Sovyetlerin Türkiye'ye yönelik tehditvari açıklamaları ile Akdeniz'de meydana gelen askeri hareketliliğin, Türk devlet adamlarını tedirgin ettiği ve bundan sonra da şimdiye kadar takip edilen tarafsızlık politikasının devam ettirilip ettirilemeyeceğinin dikkate değer olduğu belirtilmiştir.

\section{2) Türkiye Basınında Adana Görüşmeleri}

\section{a) 3 Şubat 1943 Ulus (Ankara) Gazetesi}

Ulus Gazetesi'nin yorumuna göre; İngiliz Başbakanı iki günlüğüne Cumhuriyet Hükümetinin misafiri olmuş ve Cumhurbaşkanı İsmet İnönü tarafindan kabul edilmiştir. Başvekil Winston Churchill, Türkiye'nin baştan beri açık ve kesin olan tarafsızlık politikasını bizzat en yetkili erkan ile görüşmüş, Türkiye'nin savunma durumunu görme firsatı bulmuştur.

Görüşmelerin, Kazablanka buluşmasının hemen arakasından yapılması ile sorunlar açık olarak ve iki ülkenin dostane tutumlarını geliştirmesi ile sonuçlanmıştır. Bilhassa Amerikan Başkanının düşüncelerinin tam olarak Ankara'ya iletilmesi Başkana olan sempatiyi artırmıştır. Türkiye'nin bir istikrar adası olarak tarafsızlık politikası müttefikler tarafından memnuniyet uyandırmıştır ${ }^{46}$.

\section{b) 3 Şubat 1943 Vakit (İstanbul) Gazetesi}

Asım US tarafından kaleme alınan yazıda; büyük devlet adamı Churchill, Adana'da Cumhuriyet Türkiye'sinin misafiri olarak iki gün kalmış, iki ülkenin en üst seviye askeri ve sivil idarecileri ile harp ve sulh meselelerini görüşmüştür.

Misafir İngiliz Başbakan, Amerikan Başkanı'nın sevgi ve sempatisini de İsmet İnönü'ye iletmiştir. Görüşmelerde Türkiye'nin tarafsızlık siyaseti ile savunma tedbirlerinin yanı sıra harp sonrası meseleler konuşulmuştur. $\mathrm{Bu}$ görüşmenin özellikle 3'üncü bir ülkenin aleyhine bir tavır olmadığı açıktır. Türkiye'nin milletler arası siyasetinde bir değişiklik olmasının beklenmediği değerlendirmesi yap1lır ${ }^{47}$.

${ }^{46}$ AYIN TARİHI, "AKİSLER, Şubat 1943,s.117

${ }^{47}$ AYIN TARİHI, “AKISLER, Şubat 1943, s.117,118 


\section{c) 3 Şubat 1943 Yeni Sabah (İstanbul) Gazetesi}

Hüseyin Rahmi GÜRPINAR tarafından kaleme alınan yazıda, Adana Görüşmesinin dünyada çok büyük ilgi uyandıracağı açıktır. Bu görüşme ile iki ülke arasındaki dostluk bağları her iki tarafı memnun edecek şekilde yeniden görüşülmüştür. Bazı ecnebi devletlerin iddia ettiği gibi Başbakan Winston Churchill Türkiye'ye, politikalarımızı değiştirmemizi tazyik etmek amacıyla gelmemiştir. Türkiye'nin savunmasını güçlendirmek için gerekli malzeme ve teçhizat desteği konusunda mutabık kalınmış, Türkiye'nin milli menfaatlerine önem verildiği bir kez daha anlaşılmıştır. Görüşmelerde harp sonrası meselelerin çok karmaşık olacağının değerlendirilmesi yapılmıştır. Türkiye'nin bulunduğu coğrafyanın bir özelliği olarak; Balkan, Akdeniz, Asya devleti olması nedeniyle yakınında gelişen olaylara karşı söyleyeceği bir şeyler olması doğaldır. Bir kısım propagandalar ile dostumuz Sovyetler ile aramızı açmak isteyenler vardır. Müttefiklerimizi de itham etmektedirler. Oysa Amerika ve İngiltere'nin amacı harp sonrası Türkiye'nin herhangi bir taarruza uğramamasıdır. Kahire Radyosu, Adana Mülakatı'nın, Stalin'in ve Roosevelt'in bilgisi dahilinde bulunduğunu ve bu mülakat ile dedikodulara son darbenin vurulduğunu işlemiştir ${ }^{48}$.

\section{ç) 3 Şubat 1943 Son Posta (İstanbul) Gazetesi}

Ekrem Uşaklıgil, Son Posta Gazetesinde konuyla ilgili olarak, İngiliz Başbakanın 10 gün devam eden bir konferanstan sonra $5.000 \mathrm{~km}$. daha yol teperek Türkiye'ye gelmesinin, Türkiye tarafindan izlenen faydalı olma ama taraf olmama politikasının bir sonucu olduğunu belirtmiştir. Yazısının devamında, ilişkilerin daha da kuvvetlendiği, Türkiye'nin son 20 yıldır hiç taarruz fikri taşımadığı, daima savunmasına ağırlık verdiği ve gelen tehlikeyi önceden görerek tedbir aldığı ve dinamik bir politikanın işletildiği görüşüne yer verilmiştir ${ }^{49}$.

\section{d) 4 Şubat 1943 Cumhuriyet (İstanbul) Gazetesi}

Yunus Nadi ABALIOĞLU, Churchill'in Avam Kamarasındaki açıklamasından yararlanarak yaptığı yorumda şu hususlara yer vermiştir. Müttefiklerin Türkiye'yi harbe sokmak gibi bir niyetleri olmamıştır. Türkiye'nin ihtiyacı olan askeri malzemelerin imkanlar dairesinde bir an evvel Türkiye'ye verilmesi kararlaştırılmıştır. Türkiye, yalnız bu harp içinde değil, harpten sonra da yaşanacak süreçte dünya barışına katk1 sağlayacaktır. Türk Devleti kendisine saldırı olmadıkça taraf olmayacaktır. Türkiye, müttefikler ile olduğu gibi Almanlar ile olan dostluğunu sürdürecektir. Bu

${ }^{48}$ AYIN TARİHI, “AKİSLER”, Şubat 1943, s.118,119

${ }^{49}$ AYIN TARİII, “AKİSLER”, Şubat 1943, s.120 
kapsamda Almanya, Türkiye'nin milli savunmasını geliştirmesine bütün samimiyetiyle destek olmuştur, yorumunu yapmıştır. Nadir Nadi, Türkiye'nin tarafsızlık üzerine bina edilen başarılı dış politikasında en büyük payın İsmet İnönü olduğunu belirtmekteydi.

\section{e) Diğerleri}

Adana Görüşmeleri bütün dünyada geniş yankı bulmuş olmakla birlikte, en çok Türk basınında gündeme alınmıştır. Bahsedilen gazeteler dışında; Son Telgraf, Tasvir-i Efkar, İkdam, Adana'da yerel,“Türk Sözü Gazetesi”, Yeni Asır, Tan, Vakit Gazetesi farklı tarihlerde konuyla ilgili geniş değerlendirmelerde bulunmuşlardır ${ }^{50}$.

\section{Adana Görüşmelerinin Siyasi ve Askeri Yönden Değerlendirilmesi}

2'nci Dünya Savaşı yıllarında savaşın en yoğun olduğu bir dönemde politik yönü oldukça önemli ve Adana'da bir trende yapılan görüşme, İngiliz Heyetin Türkiye'yi terk ettiği 3 Şubat 1944 yılına kadar iki tarafı da bir yıldan daha fazla bir süre meşgul etmiştir. Görüşmeler Türkiye'yi askeri ve siyasi yönden etkilemiştir ${ }^{51}$. İngiltere, Türk ordusunu desteklemek için bir takım çalışmalar yapmış ve taraflar arasında görüşmeler sürdürülmüştür. Heyetler arasında yapılan görüşme süreci savaşın sonucunun belli olmadığ 1 , Almanların Balkanlarda ve Akdeniz'de hala en büyük güç olduğu bir döneme rastlamış olması bakımından önemli olmuştur. Türkiye'nin savaşa girmesi halinde Alman mevzileri ile 60-100 km sonra karşılaşacak olmasi gerçeği, Türk yetkililerin tarafsız kalma kararında etkili olmuştur. Diğer yandan, bu savaşın Türkiye'nin savaşı olmadığı inanc1, görüşmelerin sonuçları bakımından Türkiye'nin politikasına tesir etmiştir.

\subsection{Adana Görüşmelerinin Siyasi Yönden Değerlendirilmesi}

Türkiye'nin savunmasını güçlendirme konusu görüşmede en çok üzerinde durulan husus olmuştur. Resmi açıklamalar, basına yansımalar genelde bu kapsamda ele alınmıştır.

İngiliz Başbakanı, askeri destek için silah ve techizat verip Türkiye'yi müttefiklerin yeni aktif muharip gücü yapacağını umarken, Türkiye tarafindan görüşmelerde gündeme getirilen ve karşılanması kısa zamanda mümkün olmayan listelerle kendi siyasetinin kurbanı olmuştur.

${ }^{50}$ AYIN TARİHİ, “AKISLER”, Şubat 1943,s.108-137

${ }^{51}$ T.C. Dışişleri Bakanlığı, a.g.e., s.42,43 
Adana Görüșmesi sonucu yayınlanan bildiride; "Türk devlet adamlart son buhranlı seneler esnasında güdülen Türk politikasının cereyan seyrini izah etmişler ve Başvekil Churchill, Majeste kral hükümetinin bu politikayı sempati ve tam anlayışla takip ettiğini kendilerine temin eylemişlerdir. Büyük Britinya ve Amerika Birleşik Devletleri'nin, Türkiye'nin umumi bakımdan tedafii emniyetini kuvvetlendirmek için malzeme itibariyle yapabilecekleri yardımın şekli ïzerinde mutabık kalınmış ve bu mevzuu üzerinde iki taraf askeri mütehassıslart arasında görüşmeler vuku bulmuştur." ifadesi yer almıştır.

Churchill bu görüşmeler sonrası muhtemel tepki ve farklı yorumları dikkate alarak açık politika izlememeyi tercih etmiştir. Kahire'de verdiği beyanatta, Adana Görüşmelerine değinirken askeri yönüne atıfta bulunmamış, 11 Şubat 1943 tarihinde Avam Kamarası'nda yaptı̆̆ konuşmada ise yalnız askeri boyutunu değerlendirmiştir. Churchill, Avam Kamarası'nda yaptığı konuşmada, Türkiye'nin dürüst ve sağlam duruşu ile düşman güçlerin Irak ve Suriye'yi işgallerini engellediğini belirtmiştir. Yine Türkiye'nin bu tavrı ile Irak ve İran petrollerinin düşman ülkelerin ele geçmesine de mani olduğunu açıklamıştır ${ }^{52}$.

Churchill, Adana Görüşmeleri ile siyasi bir manevra yapmak istemiştir. Türkiye Cumhurbaşkanı ve ekibi gerçekçi oldukları ve savaşın seyrini doğru değerlendirdikleri için tezlerini iyi savunmuşlar ve sağlam bir duruş sergilemişlerdir. Oysa daha ziyade siyasi bir yaklaşım içinde bulunan Churchill, gerçeklerle yüzleştiğinde Türk heyete hak vermek durumunda kalmış ve beklentilerini elde edememiştir. İngiliz Başbakanına Almanya'nın yıkılması durumunda, Sovyetler Birliği'nin ne kadar büyük bir Avrupa sorunu olacağı özellikle vurgulamaya çalışılmış, bununla birlikte Churchill'in bu tehdidi tam olarak algıladığını söylemek mümkün değildir. Görüşmeler; mihver ve müttefikler ve müttefik ülkeleri destekleyen ülkelerde farklı yorumlara neden olmuştur. $\mathrm{Bu}$ durumdan rahatsız olan Churchill, görüşmelerin altında tutanakta yazandan başka bir şey aranmamasını Avam Kamarasından talep etmiş ve Türkiye'ye gaileler yaratmanın İngiliz siyasetinin tarzı olmadığını, Türkiye için tehdit olan her şeyin İngiltere ve uluslararası camia için de tehdit olduğunu söylemiştir. Açıklamasında; Türkiye'den askeri savunmasını en üst seviyeye çıkarmaktan ve askeri savunmayı tanzimden, ulaştırma hatlarının düzenlenmesinden

${ }^{52}$ BCA, T.C. Hariciye Vekaleti (Rauf Orbay'ın 4 Sf. Londra Raporu), 11 Şubat 1943, 030. 10, 235, 588, 3, Rp.Sf.1,2 
başka bir talepte bulunulmadığ 1 , bu amaçla da Ankara'da askeri komisyonların çalışmaya başladığı değerlendirmesini yapmıştır ${ }^{53}$.

Adana Görüşmeleri'nde Türkiye ortada açık bir antlaşma olmadığından hiçbir taahhüt altına girmemiştir. Churchill bu konuyu Avam Kamarası'nda da dile getirmiş ve bu konuda yaptığı açıklamada; "Türk dost ve müttefiklerimizden bir şey istemedik, kendilerini tehlikeye atmak arzusunu da göstermedik. Çünkü Türkiyenin tehlikeye düşmesi bizim tehlikeye düşmemiz olurdu..." demiştir ${ }^{54}$. Bununla birlikte İngiliz Başbakan, Türkiye'nin 1943 yılı içinde savaşa taraf olacağını ümit ediyordu. Almanya'ya karşı yapılacak ve kesin netice alınacak bir savaş için bunu gerekli görüyordu. Yılın ortalarına doğru bu ilişkiler beklenenin aksine soğumaya başlamıştır. İnönü ve ekibi tarafsızlık politikası ile İngiltere'nin memnun edilemeyeceğini bilmektedir. Bununla birlikte, İngiltere'nin mevcut koşullarda Türkiye'den vazgeçemeyeceğini değerlendirerek Türkiye'nin takip ettiği dış politikada değişiklik yapılmamıştır. Çünkü Almanlar hâlâ büyük bir tehdit durumundadır. Adana Görüşmelerinde uzlaşılan en önemli konu, Türkiye'nin hızla müttefik silahları ile silahlandırılması olmuştur ${ }^{55}$. Bu görüşmelerin, Ankara ile Moskova arasında ilişkilerin düzelmesi için de bir başlangıç olacağ1 ümit edilmiş fakat bu girişim beklenen neticeyi vermemiştir. Churchill, Stalin'e yazdığı bir mektupta, Türkiye'nin girişimini, “yarı yolda karşılamasını” rica eder. Artık iki yıl evvel Almanlar karşısında yenilen ve saldırıya uğrayan Sovyetlerin yerinde, elde edilen askeri başarılar ile özgüvenini kazanmış ve bölgesinde güç odağı olmuş bir Sovyet gücü bulunmaktadır. Bu gelişme doğal olarak, Türkiye'nin endişesini arttırmıştır.

Türkiye, 1943 y1lından sonra kazanan ya da kaybeden taraftan ziyade gücünü savaş sonrasına saklamak durumunda kalmıştır. Çünkü son gelişmeler ile Sovyetlerin olası tehditlerine karşı, bir gerginliğin çıkması ihtimali daha da önem kazanmışıır ${ }^{56}$. Türkiye, olası bir Sovyet saldırısına karşı hazırlıklı olmak zorunda olduğunun farkındadır.

Adana Görüşmeleri’nin yapıldığı 1943 yılının ilk aylarında İngiliz basını Türkiye lehinde yazılar yazarken, görüşmelerin kitlenmesi ve uzaması sonrasında Türkiye suçlanmaya başlanmıştır. İngiltere'nin bütün gayretlerine rağmen savaşın en yoğun zamanlarında Türkiye müttefikler safında sıcak

${ }^{53}$ AYIN TARİHI, "VESIKALAR”, Şubat 1943,s.195; ÖZTOPRAK, a.g.m.,s.192, 194

${ }^{54}$ BCA, T.C. Hariciye Vekaleti (Rauf Orbay'm 4 Sf. Londra Raporu), 11 Şubat 1943, 030. 10, 235, 588, 3, Rp.Sf.2,3

55 Berna DÖNMEZ, "İkinci Dünya Savaşı'nın Son Döneminde Türk Dış Politikası”, Altıncı Askeri Tarih Semineri Bildirileri II İkinci Dünya Harbi ve Türkiye 20-22 Ekim 1997İstanbul, Gnkur.Bsm., Ankara, 1999, s.510-514

${ }^{56}$ YALÇIN (Der.), a.g.e., s.155, s.45-70 
çatıșmanın taraftarı olmamıștır. Türkiye harbin sonuna doğru müttefiklerin isteklerine uymuş, yeni dünya düzeninde yerini almak için gerekli adımları atmıştır. 2 Ağustos 1944'de Almanya ve 3 Ocak'ta Japonya ile ilişkiler kesilmiștir ${ }^{57}$.

Churchill'in, Nisan ayında yaptığı tehditvari konuşmaya rağmen 2 Ağustos 1944 tarihinde Avam Kamarası'nda yaptığ 1 konuşma dikkate değer farklılıklar göstermektedir. Bu konuşmasında, Türkiye'nin bu güne kadar olan süreçteki tereddütlerinde tamamen haklı olduğu, Türk ordusunun 1'inci Dünya Savaşı'ndan kalan silahlar ile teçhizi nedeniyle modern harp silah ve araçlarına sahip olmadığı, kendini yenileyemediği ve Adana Görüşmeleri sonrası müttefikler safına zorunlu olarak giremediğini söylemiştir ${ }^{58}$. Bilahare, Türkiye tarafından 23 Şubat 1945 tarihinde Almanya ve Japonya'ya karşı savaş ilan edilmiştir ${ }^{59}$. Savaşın bitmesine kadar müttefiklerin Türkiye'den zaman zaman bazı talepleri olmuştur. Müttefiklerin Suriye ve Irak arasındaki demiryollarının kullanımı için istedikleri müsaade, Türkiye'nin artık müttefikler safinda yer alması nedeniyle uygun bulunmuştur. Konu ile ilgili zamanın Hariciye Vekili Hasan SAKA tarafından yapılması gerekenler Başbakanlığa sorulmaktadır ${ }^{60} . \mathrm{Bu}$ dönemden sonra Türk-İngiliz ilişkileri daha da güçlenmiştir. Türkiye savaş sonrası oluşacak yeni dünyada kendine müttefikler safinda yer bulmayı politik bir tercih olarak benimsemiştir.

\subsection{Askeri Yönden Değerlendirilmesi}

Askeri teçhizat ve silah desteği sağlanarak, Türkiye'nin direnme noktası olan ve Sovyetlerin tehdit olduğu iddiası çürütülmek isteniyordu. Ancak yapılan görüşmeler sonucu taahhüt edilen silah ve techizatın, kendi amaçlarına hizmet etmesi için taahhüt edildiği anlaşılmaktadır. Türkiye'nin çıkarları ve güvenlik endişeleri dikkate alınmamıştır. Bu durum, Chuchill'in 11 Mart 1943 tarihinde Stalin'e yazdığ mektupta, Türk hava alanlarının kullanımı için uygun bir zamanda, Türklerden ricada bulunacağını belirtmesi ile daha da açık olarak anlaşılmaktadır ${ }^{61}$. İngilizlerin, Türkiye'nin ihtiyacı olan modern hava alanlarını inşa ederek aynı zamanda kendilerinin kullanmak istedikleri görülmektedir. Chuchill, 11 Şubat 1943 tarihinde Avam Kamarasında yaptığı konuşmasında Türkiye ile Sovyetlerin sıkı

57 AYIN TARİHI, "Türkiye Almanya ile Münasebetini Kesti”, Ağustos 1944,s.66-92; YALÇIN-AVCI, a.g.e., s. 459

${ }^{58}$ AYIN TARİiI, "Türkiye Almanya ile Münasebetini Kesti”, Ağustos 1944,s.66-92

59 AYIN TARİḢ,“'Türkiye'nin Almanya ile Japonya'ya Harp İlanı”, Şubat 1945,s.35-66; YALÇIN-AVCI, a.g.e., s. 459

${ }^{60}$ BCA, T.C. Hariciye Vekaleti, 030. 10, 152,78,30

${ }^{61}$ ÖZTOPRAK, a.g.m., s.190,191 
dostluk kurmasına taraftar olduğunu açıklamıştır ${ }^{62}$. Churchill, Türkler ile Rusları aynı safta bir araya getirmeye gayret etmiş olmasına rağmen, Stalin'in başarı kazandıkça Türkiye'ye bakışı farklılık göstermeye ve söylemleri sertleşmeye başlamıştır. Bu görüşmelerin sonucu olarak pek çok Türk Askeri Heyeti, İngiliz askeri birliklerinden alınacak yeni silah sistemi ile ilgili kursa tertip edilmiştir ${ }^{63}$. Bu kapsamda Türk havacılar İngiliz üslerinde eğitime alınırlar. Türk havacılık tarihinde Fransız etkinliği yerini İngilizlere bırakmaya başlamıştır. Savaş yıllarında 300 civarında Türk pilot İngiltere'de pilotaj eğitimi almıştır.

Adana Görüşmeleri sonucu Türkiye'ye verilecek bir liste oluşturulmuştur. Bu liste Adana Listesi olarak tanımlanmıştır. Bundan sonra dahil olan ilaveler bu listeye zeyl olarak; A, B ve C isimleri ile dahil edileceği belirtilmiştir ${ }^{64}$.

Görüşmeler sonrası askeri alanda yapılacak destek ve donanımlar için Türkiye harekete geçmiş ve 4 Şubat 1943 tarihinde Genelkurmay II. Başkanlığına bağlı "Malzeme Tahakkuk ve Takip Bürosu" kurulmuştur. Büroda, hava, kara ve deniz subaylarından teşekkül eden bir birim oluşturulmuş ve birim faaliyete başlamıştır ${ }^{65}$. Milli Savunma Bakanlığ 04 Şubat 1943 tarih ve 53073 sayılı tezkere ile yardımın tatbiki için bazı heyetleri yardım merkezlerine göndermeye başlamış, ilk etapta Mısır'da bulunan 16 uçağın Türkiye'ye getirilmesi için 10 havacı personel görevlendirilmiştir ${ }^{66}$. Askeri malzemenin sevki için 26 Şubat 1943 tarihinde Türk Askeri Heyeti Orgeneral Asım Gündüz ve İngiliz Heyeti Tümgeneral A. C. Arnold Başkanlığında toplanmış ve malzeme sevkinin detayları görüşülmüştür. Günde 500-1000 ton arası malzeme gönderilmesi planlanmış ve bu işlerin yapılabilmesi için aşamalı olarak uygulanan bir sistem oluşturulmuştur. Buna göre;

a. Hava alanlarının savunması için uçaksavar topları ile birlikte 25 hava filosunun gelmesi,

b. İki hafif iki ağır uçaksavar bataryası ve iki uçaksavar taburunun gelmesi,

${ }^{62}$ BCA, T.C. Hariciye Vekaleti (Rauf Orbay'ın 4 Sf. Londra Raporu), 11 Şubat 1943, 030. 10, 235, 588, 3, Rp.Sf.1,2

${ }^{62}$ BCA, T.C. Hariciye Vekaleti (Rauf Orbay'ın 4 Sf. Londra Raporu), 11 Şubat 1943, 030. 10, 235, 588, 3, Rp.Sf.3

${ }^{63}$ ÖZTOPRAK, a.g.m., s.191,194

${ }^{64}$ ÖZTOPRAK, a.g.m.,s.194,195; DÖNMEZ,a.g.m., s.510-513

${ }^{65}$ ÖZTOPRAK, a.g.m., s.190-195

${ }^{66}$ BCA, T.C. Milli Müdafaa Vekaleti ve Maliye Vekaleti,11Şubat 1943, 030. 10, 133, 957, 18, Rp.Sf. 1,2 
c. İki zırhlı alay gelmesi planlanmıştır. Ancak daha sonra Türk tarafı bu sevkiyatı yetersiz bulmuştur.

Toplam sevk edilecek malzeme miktarı 3,5 milyon ton civarındaydı. Türk limanları ve demir yollarının günlük malzeme sevk kapasitesi ise 1.100-1.400 tondu. Bu durumda, yılda 560.000 ton malzeme alınabilecekti. 3,5 milyon ton malzemenin alınması mevcut kapasite ile ancak 6 yılda mümkün olabilecekti. Türkiye'ye vaat edilen yardımların zamanında teslimi ve Türkiye'nin 1943 yılı sonuna kadar harbe sokulması için;

a. Limanların tahmil ve tahliye kapasitesinin artırılması,

b. Sevk için daha fazla deniz taşıtı tahsis edilmesi,

c. Mersin ve İskenderun Limanlarından iç bölgelere demiryolu nakliyat gücünün artırılması,

d. Kömür tedarik edilmesi,

e. Demiryollarının kapasitesinin zorlanması ile birlikte karayollarını geliştirmek ve kara taşıtları için gerekli yakıtın temin edilmesi gerekmeydi ${ }^{67}$.

Almanya'daki Türkiye Ataşesi, 7 Aralık 1939 tarihinde Genelkurmay'a bir rapor göndermiştir. Rapora göre Türk dostu bir Alman general Almanya'nın Türkiye ile ilgili planlarından bahsetmiş ve alınması gerekli tedbirler ile ilgili bazı tavsiyelerde bulunmuştur. Buna göre; Almanya için Türkleri Trakya'dan atmak tarihi bir emeldir. Türkiye kendini savunabilmek için Trakya'da en az iki zırhlı tümen bulundurmalı, silahlar için gerekli cephaneyi üretecek fabrika kurmalı, Trakya'da Hava Kuvvetlerini güçlendirmeli ve Kafkasya Cephesi'ne de önem vermelidir. Nitekim Trakya'da oluşturulan Çakmak Hattı, düşmana karşı savunma yapmayı esas almıştır. İngilizler verdikleri askeri destekle ilk başta olmasa bile kısa süre içinde Türkiye'yi savaşa dahil etmeyi ümit etmektedir. Türkiye, İngilizlerin vaat ettiği silahları alarak ordusunu silahlandırmaya gayret etmiş ama bağlayıcı taahhütlere girmemeye özen göstermiştir. Türk ordusunun elinde 1905 yılından itibaren harplerde kullanılmış eski toplar bulunmaktaydı. Bu topların 114 farklı çeşitte olması idame-işletme sıkıntısını beraberinde getirmekte ve bu maksatla Türkiye, ordunun silah ve cephanesinin yenilenmesi ve atış gücü yüksek silahları bir an evvel almak istemiştir.

\footnotetext{
${ }^{67}$ Musa ÇAKIR, "İkinci Dünya Savaşı Döneminde Askeri Lojistik Hizmet ve Destek Sağlamaya Yönelik İngilizlerle Yapılan Temaslar", Altıncı Askeri Tarih Semineri Bildirileri 1 İkinci Dünya Harbi ve Türkiye 20-22 Ekim 1998-İ́stanbul, Gnkur.Bsm., Ankara,1998,s.405-407
} 
Adana Görüşmelerinde, Türk tarafinca 258 uçak talep edilmiştir ${ }^{68}$. Altı yeni filo kurulması ve her filonun 24 uçaktan oluşması, ayrıca 12 adet de işletme yedeği bulunması planlanmıştır. Türkiye bu taahhütlerin ancak \% 57'sini alabilmiștir. Yeni alınan sistemlerde kısa süre sonra idame ișletme sorunu ortaya çıkmıştır. Bu nedenle Türk uçaklarının çoğu arızalı duruma düşmüş ve uçak faaliyet oranı \% 50 civarında kalmıştır. Havacılık ortaya çıkışından itibaren, ileri teknoloji gerektirdiğinden ve bu alanda Türkiye'nin birikimi olmadığından dışa bağımlılık had safhadaydı.

Malzemelerin Türkiye'ye teslimi için oluşturulan komisyon çalışmaları istikrarlı ve hızlı bir performans göstermemiştir. İngiliz komisyonu Türklerin ne istediklerini tam olarak bilmediklerini ve işi yavaşlattıklarını ileri sürmüştür. Örneğin Türk ve İngiliz Hava Teşkilatı aynı olmasına rağmen ihtiyaç duyulan 130 telsiz için Türkler 130 kamyon istemiştir. Oysa İngilizler 24 telsizi bir kamyona koymak suretiyle 6-7 kamyonla aynı işi yapmaktadırlar. Türkiye'de yapılması gereken yol ve diğer altyap1 hizmetlerine Türkiye tarafından geç izin verilmiş ve sürekli zaman kaybedilmiştir.

Türkiye'nin savaşa hazır hale getirilmesi için günde 10.000 ton silah sevkiyatı yapılması gerekiyordu. Ayrıca silah ve teçhizatı kullanacak Türk askerinin yetiştirilmesi ve eğitimden geçirilmesi de gerekiyordu. Bu konuda İngiliz birliklerinden alınan eğitim yanında Ankara'da bir okul açılması görüşülmüştür. En önemli aksaklıklardan biri ise Türkiye'ye sevk edilen silahların bir kısmı daha evvel İngilizler tarafından savaşlarda kullanılmış, envanter dışı bırakılmış, yedek malzeme temininde ve bakımında büyük külfetler olan silahlardı. Yine heyetler arasında diğer bir problem yabancı dil sorunuydu. Türk heyet ile İngiliz heyet arasında iletişim önemli problemlerdendi ${ }^{69}$. Bununla birlikte çalışmalar devam etmiştir. Görüşmelerde karşılıklı mutabık kalınan ve Türkiye için gerekli olan kiralanacak olan 5 adet geminin 2 âdedi 30 Nisan 1943 tarihi itibariyle hareketi beklenmekte, diğer 3 âdedinin ise yazışmaları başbakanlık ile

\footnotetext{
${ }^{68}$ NOT: Bu rakam farklı yerlerde farklı geçmektedir. CEBECİOĞLU, a.g.m.,s.348; 216 Av, 216 Bombardıman, 36 Ağır Bombardıman, 36 Gözetleme Av, 6 Deniz Keşif,100 Magister, 75 Falcon 75Anro-Anson olarak geçmektedir. Bu dönemde Türk Ordusunda yaklaşık 780-815 civarında uçak olduğu değerlendirildiğinde (Rifat UÇAROL, 6. Tarih Semineri II, s.524540) 2'nci bir Hava Kuvveti istenmiştir. Başka bir yerde de 40 filo tabiri bu bilgiyi doğrulamaktadır. Müttefiklerin uçak üretiminin 600.000 civarında olduğu düşünüldüğünde Türkiye'ye göre abartılı gözüken rakamların pek de fazla olmadığı görülmektedir. Kaldı ki, üretilen toplam uçak sayısı bir milyon civarındadır.

${ }^{69}$ ÇAKIR, a.g.m.,s.411-413
} 
bakanlıklar arasında devam etmektedir ${ }^{70}$. İngiliz Askeri Heyeti Başkanı Korgeneral Lindell, verilen malzemelerin kullanılamadığından ve bakımının yapılamadığından şikayetle Genelkurmay Başkanlığına yazı yazmış, bunun üzerine verilen cevapta, bu dönemde 192 personel bakım kursundan geçmiş, 603 yeni top için 128 subay kurs almıştır. Ancak gelen top sayısı 378 olup 225 adet daha ihtiyaç olduğu 31 Ocak 1944'te diğer aksakl1klarla birlikte bildirilmiştir ${ }^{71}$

\subsection{Sonuç}

Adana Görüşmeleri sonucunda, İngiltere en kısa zamanda Türkiye'yi savaşa dahil etmek için Ortadoğu Kara, Ortadoğu Deniz ve Ortadoğu Hava Kuvvetleri Komutanlarının hemen Ankara ile müzakerelere başlaması için görevlendirmiştir. Ancak görüşmenin bu seviyede yapılması Ankara tarafindan uygun bulunmamıştır. Korgeneral Lindell başkanlığındaki bir heyet ile görüşmeler başlamıştır. Heyet hava savunması ve üs hazırlıklarını görüşmek için Ankara'ya gelmiş ve Türk Heyetin askeri malzeme konusu çözümlenmeden diğer konulara girmek istememesi üzerine müzakereler çıkmaza girmiştir.

Müzakerelerin kesilmesi üzerine Türk-İngiliz Dışişleri Bakanlıkları arasında mektup düellosu başlamıştır. İngiliz Askeri Heyet 3 Şubat 1944'te ansızın Ankara'yı terketmiştir. İngiliz Büyükelçisi Hugessen, heyetin Ankara'dan herhangi bir sebep göstermeksizin Kahiye'ye hareket etmesinin istenildiğini, askeri malzeme sevkinin durdurulduğunu, zorunlu olmadıkça temasda bulunulmayacağını, ticari mal sevkiyatı için bir sorun olmadığını bildirmiştir. 1 Nisan 1944 tarihinde Amerika tarafından; "Kiralama ve Borç Verme Yasası" kapsamında verilen yardım da durdurulmuştur. Churchill, 1943 y1lında Türkiye'ye 20 milyon İngiliz Sterlini değerinde İngiliz ve Amerikan yardımı verildiğini, Türkiye'nin 1944 Şubat ve Mart aylarında savaşa girmesini beklediklerini, hiç olmazsa üs vereceğini umduklarını ancak bunun olmadığını ve artık ümitlerinin kalmadığını belirtmiş ve Türkiye'yi desteklemeyeceklerini söylemiştir ${ }^{72}$.

30-31 Ocak 1943 tarihinde büyük bir ümitle Türkiye'ye gelerek görüşmelerde bulunan, ve Türkiye'yi peşinden sürükleyeceğini ümit eden Churchill bu politikasında beklentisini elde edememiştir. Harbin en sıkışı zamanlarında Almanya'nın Ege Adalarından bir kısmını ve Edirne sınırında bazı düzeltmeler yapmayı Türkiye'ye teklif etmesi, diğer taraftan

70 BCA, T.C. Başbakanlık, Münakalat ve Maliye Vekaleti,11Şubat 1943, 030. 10, $169,177,20$

${ }^{71}$ CEBECİĞLUU, a.g.m., s.366-368

${ }^{72}$ CEBECIOĞLU,a.g.m., s.364-366 
müttefiklerin Ege Adaları ve Suriye'nin bir kısmını Türkiye'ye vermeyi teklif etmeleri Türkiye tarafından dikkate alınmamıştır ${ }^{73}$. Hatta Türkiye'nin kimsenin topraklarında gözü olmadığı ssrarla dile getirilmiştir. Türk Devleti, muhtemel sıcak gelişmelere karşı oldukça temkinli davranmış, Türk ordusunun harp içinde yıpranmaması ve harp sonrası gelişmeler karşısında güçsüz kalmaması için tedbir alınmıştır. Türkiye, harp süresince son Alman askerinin, son Rus askerinin üstüne düşmesini büyük bir sabırla beklemiştir ${ }^{74}$.

Türkiye bu dönemde, düşmanlar arasındaki dengeleri iyi kullanmıştır. Almanya'dan 100 milyon Marklık bir kredi alınmış ve orduyu modernize etmek için çalışma başlatılmıştır ${ }^{75}$. Hemen akabinde başlayan İngilizAmerikan yardımı ile ordunun modernizesi hızlandırılmıştır. Esasen 19 Ekim 1939 Anlaşması sonrası Türkiye, müttefiklerden silah malzemesi almaya başlamış, daha sonra ikili görüşmeler ve yapılan antlaşmalar ile yardımın kapsamı genişletilmiştir.

Adana Görüşmeleri yardıma farklı bir boyut katmış ve Türkiye ihtiyacını bir bütün olarak ortaya koyma imkanı bulmuştur.

Türk ordusunun asker mevcudu harp yıllarında 1.700 .000 kişiye kadar ulaşmıştır. Bu durumu iyi analiz eden ve Türklerin savaşçı özelliğini bilen Churchill, Alman tehdidinde piyade unsuru olarak Türkiye'yi saflarına çekmek istemiştir. Ancak Chuchill'in gözden kaçırdığı önemli bir ayrıntı ise; Türkiye'nin 1930'ların başından itibaren yaptığ 1 ittifaklar, girişimler ve anlaşmalara dayanarak tarafsızlık politikasına sıkı olarak bağlı kalmasıydı. Çünkü, savaşın tarafları için 1'inci Dünya Savaşı'nın adilane olmayan sonuçlarını bu savaşta büyük risklere rağmen yenilenler değiştirmeye, kazananlar ise muhafaza etmeye çalışacaklardı. Bu gerçekten hareketle Türkiye, çok çetin olacağ 1 görülen milletler arası hesaplaşmaya taraf olmak istememiştir. Almanya, Sovyetler Birliği ve İtalya bu haksızlıkların giderilmesi için yıllarca uluslarını savaşa hazırlamıştır. Türkiye, Misak-1 Milli ile sınırlarını çizmiş ve asırların verdiği yıkımı tamir etmek ve medeni ülkeler arasında yer almak için köklü değişimler yapmaya çalışıyordu. Üstelik "Yurtta Sulh, Cihanda Sulh" prensibini benimsemiş olduğundan taarruzi harp için bir planı ve hedefi bulunmuyordu. Askeri hareketlilik yalnızca Türkiye'nin milli sınırlarını savunmasına yönelikti. Başbakan Churchill bu gerçeği anlamak istememiştir. Kaldıki, müttefikler kısa süre

\footnotetext{
${ }^{73}$ YALÇIN (Der.), a.g.e., s.155, s.133,134; William Hale, a.g.e.,s.82,83

${ }^{74}$ William Hale, Çev.Petek Demir,Türk Dış Politikası 1774-2000, Mozaik Yay., İstanbul, 2003, s.80-86

${ }^{75}$ William Hale, a.g.e.,s. 89
} 
önce Osmanlı Devleti'ni aralarında gizli antlaşmalarla paylaşmışlar ve bu sonradan ortaya çıkmıştı. Türkiye bu gerçeği de gözardı edemezdi. $\mathrm{Bu}$ dönemde Boğazlara yönelik gizli bir plan olabilirdi. Türkiye Cumhuriyeti Devleti,yakın geçmişte yaşanan acı gerçeklerden hareketle müttefiklerin her türlü yazılı taahhütlerine şüphe ile bakmak durumunda kalmıştır.

Savaş sonrası Avrupa'nın güç dengesinin Sovyetler Birliği olacağının anlaşılması ve 1942 sonrası Rus söyleminin ve üslubunun sertleşmeye başlaması Türkiye'yi iyiden iyiye tedirgin ediyordu. Oysa Batılı devletler ve Amerika bu gerçeği bütün çıplaklığına rağmen göremiyordu. Nitekim 1925 yılından beri devam eden Türk-Sovyet Saldırmazlık Paktı, 1945 yılından itibaren Sovyetler tarafindan uzatılmadı. Montreux Boğazlar Sözleşmesindeki değişiklikler ile Türkiye'nin bazı doğu illerinin Sovyetlere verilmesi talebinde bulunur ${ }^{76}$.

Balkanlarda Almanlara karşı açılacak bir savaşta yüzbinlerce Türk askerinin ölmesi Türkiye'ye ne sağlayabilirdi? Türkiye, 20'nci yüzyılın başında yaşanan 4 büyük savaşla oldukça zayıflamış, ülkesinin ve nüfusunun büyük çoğunluğunu kaybetmiştir. Ekonomisi, birkaç küçük kuruluş ve işletmeden oluşan, sanayiisi pek güçlü olmayan, ilkel usullerle tarım yapılan, yer altı kaynakları zenginliğine rağmen milli kimliği oluşumunu henüz tamamlamamış, büyük harbin yaralarını sarma süreci devam eden 18 milyonluk Türkiye yeni bir savaşın riskini göze alacak durumda değildi. Kısa süre sonra görülmüştür ki, Sovyetler Birliği, Türkiye için dostane tutumunu terketmiş ve Türkiye'nin bağımsızlığına halel getirecek, toprak bütünlügünü zedeleyecek bir politika izlemeye başlamıştır ${ }^{77}$.

Türk yöneticileri Adana Görüşmelerini oldukça iyi değerlendirmişler. Müttefikler ile ilişkilerini kesmeden zaman kazanmışlar, kaybeden tarafın hangi taraf olacağının daha da belirgenleşmesini beklemişlerdir. Türkiye, İngilizlerin göndereceği destek malzemelerinin ve silah sitemlerinin tesliminde, Türk tarafın bildirdiği sırada gönderilmesini istemiş ve öncelikle İngiliz birliklerinin gelmesi engellenmiştir. Almanlara da direk cephe alınmamış ve görüşme kanalları açık tutularak düşmanlık beslemelerine mani olunmuştur. Ancak Hitler'in başarılı olması durumunda sıranın daha

\footnotetext{
${ }^{76}$ Nasuh USLU, Türk-Amerikan İlişkileri, 21. Yüzyıl Yayınları, Ankara, 2000, s.18,19; Rifat UÇAROL, “İkinci Dünya Savaş1 "Misak-1 Milli” ve Türkiye’nin Savaşa Girmemek için Direnişi”, Altıncı Askeri Tarih Semineri Bildirileri II İkinci Dünya Harbi ve Türkiye 2022 Ekim 1997-İstanbul, Gnkur.Bsm., Ankara, 1999, s.539; T.C. Dışişleri Bakanlığı, Türkiye Dış Politikasında 50 Yıl İkinci Dünya Savaşı Yılları(1939-1945), Dışişleri Yay., Ankara,1973, s.250-270

77 YALÇIN-AVCI, a.g.e.,s.4560-462; ARTUÇ, İkinci Dünya Savaşı 1.Cilt, Kastaş Yayınevi, İstanbul, 2003, s.181,182
} 
sonra Türkiye'ye geleceği gerçeği gözardı edilmemiştir. Nitekim bu hususta Almanların planları olduğu daha sonra ortaya çıkmıştır ${ }^{78}$. Saldırı nereden gelirse gelsin sonuna kadar Türkiye'nin, savunmasının yapılacağı ve bunda en ufak bir tereddüt olmayacağ 1 kararlılı̆̆ 1 Mihver ve Müttefik Devletlere her ortamda hatırlatılmıştır. Türkiye'nin yaptığı bu ikaz ve hatırlatmalar Türkiye üzerine plan yapanlara karşı caydırıcılık etkisi yapmıştır.

İkinci Dünya Savaşı'nda Türkiye'nin takip ettiği politikalar bakımından ortaya çıkan bir gerçek de; Türkiye gibi taraflara göre küçük ve askeri yönden zayıf bir devletin, dikkatli ve etkili bir politika takip etmek suretiyle, dünyanın en güçlü devletlerinin karşısında tarafsız kalabileceği gerçeğini ortaya çıkarmıştır ${ }^{79}$.

Hitler'in savaş yıllarında İsmet İnönü'ye yazdığı iki mektupta tehditvari ifadelerine karşı İnönü’nün sergilediği onurlu duruş, Türkiye'nin gerektiğinde kendini savunmakta tereddüt göstermeyecek iradeye sahip olduğunu belirtmesi bakımından önemlidir ${ }^{80}$. Nitekim aynı duruş Sovyetlere karş1 Türkiye Büyük Millet Meclisi'nde, Kazım Karabekir tarafından da gösterilmiştir. Bu dönemde Türkiye'nin önemli bir kazanımı, devlet idaresinin hemen her kademesinde ve Türk ordusunun en üst kademelerinde İstiklal Savaşı'nda yer alan komutanlar ile devletin içine düştüğü bunalımlı yıllara tanık olan idarecilerin görevde bulunması önemli katkı sağlamıştır.

\section{KAYNAKLAR}

ARŞIV KAYNAKLARI

AYIN TARİHI, “VESIKALAR”, Bas. ve Yay. Md.lüğü, Ankara, Şubat 1943

AYIN TARIHİ, “Türkiye Almanya ile Münasebetini Kesti”, Ağustos 1944

AYIN TARİHi,“'Türkiye'nin Almanya ile Japonya’ya Harp İlanı”,Şubat 1945

Başbakanlık Cumhuriyet Arşivi (BCA), T.C. hariciye Vekâleti,11 Haziran 1942, 030. 10, 232, 562, 11

BCA, T.C. Dâhiliye Vekâleti ve Muğla Valiliği, 5 Aralık 1943, 030. 10, 232, 563,9

BCA, T.C. Dâhiliye Vekâleti ve Muğla Valiliği, 13 Ocak 1944, 030. 10, 232, 563,13

BCA, T.C. Hariciye Vekâleti, 030. 10, 152, 78,30

\footnotetext{
${ }^{78}$ YALÇIN (Der.), a.g.e., s.155, s.132-134

${ }^{79}$ William Hale, a.g.e.,s. 74,75

${ }^{80}$ YALÇIN (Der.), a.g.e., s. 155
} 
BCA, Genelkurmay Başkanlığı, 030-0-010-000-000-59-402-30 Genelkurmay Arşiv Belgesi

BCA, T.C. Hariciye Vekâleti (Rauf Orbay'ın 4 Sf. Londra Raporu),11 Şubat 1943, 030. $10,235,588,3$

BCA, T.C. Milli Müdafaa Vekâleti ve Maliye Vekâleti,11 Şubat 1943, 030. 10, 133, 957,18

BCA, T.C. Başbakanlık, Münakalat ve Maliye Vekâleti,11Şubat 1943, 030. 10, 169, 177,20

BCA, 030-0-018-001-002-95-54-1,22.06.1941(Türkiye'nin Alman-Sovyet Harbine Karşı Tarafsızlı̆̆ı)

T.C. Dışişleri Bakanlığı, Türkiye Dış Politikasında 50 Yıl İkinci Dünya Savaşı Yılları (1939-1945), Dışsişleri Yay., Ankara, 1973

\section{TELIF VE TETKIK ESERLER}

Artuç, İbrahim, İkinci Dünya Savaşı 1. Cilt, Kastaş Yayınevi, İstanbul, 2003

Artuç, İbrahim, İkinci Dünya Savaşı 2. Cilt, Kastaş Yayınevi, İstanbul, 2003

ATASE Bşk.lığı, "İkinci Dünya Savaşı Kronolojisi”, Altıncı Askeri Tarih Semineri Bildirileri II İkinci Dünya Harbi ve Türkiye 20-22 Ekim 1997İstanbul, Gnkur.Bsm., Ankara,1999

Cebecioğlu,Güngör, "İkinci Dünya Savaşı ve Türk Silahlı Kuvvetleri”, 6'ncı Askeri Tarih Semineri I, İkinci Dünya Savaşı ve Türkiye 20-22 Ekim 1997-İstanbul, Gnkur.Bsm., Ankara, 1998

Çakır, Musa,"Íkinci Dünya Savaşı Döneminde Askeri Lojistik Hizmet ve Destek Sağlamaya Yönelik İngilizlerle Yapılan Temaslar”, Altıncı Askeri Tarih Semineri Bildirileri 1 İkinci Dünya Harbi ve Türkiye 20-22 Ekim 1998İstanbul, Gnkur.Bsm., Ankara, 1998

Dönmez, Berna,’’ikinci Dünya Savaşı'nın Son Döneminde Türk Dış Politikası", Altıncı Askeri Tarih Semineri Bildirileri II İkinci Dünya Harbi ve Türkiye 20-22 Ekim 1997-İstanbul, Gnkur.Bsm., Ankara, 1999

Gürün,Kamuran, "Savaşın İlk Yılı ve Türkiye", 6'ncı Askeri Tarih Semineri I, İkinci Dünya Savaşı ve Türkiye 20-22 Ekim 1997-İstanbul, Gnkur.Bsm., Ankara, 1998

Gönlübol, Mehmet, Uluslar arası Politika, Ankara Ünv.Bsm., Ankara, 1978

Hobsbawn, Eric, (Çev.Yavuz ALOGAN), Kısa 20. Yüzyıl 1914-1991 Aşııılıklar Çağı, Everest Yay., İstanbul, 2006

Kaymaklı, Hulusi, TÜRK Havacılık Tarihinde Türkler 2, Hv.Bsm., Ankara, 1997 
Kurtcebe, İsmail, "İkinci Dünya Savaşı Sonunda Türkiye Üzerinde Rus Baskısı", 6'ncı Askeri Tarih Semineri I, İkinci Dünya Savaşı ve Türkiye 20-22 Ekim 1997-İstanbul, Gnkur.Bsm., Ankara, 1998

Korbek, Ergun, "2 nci Dünya Savaşında İngiltere Başbakanı Winston Churchill ile Cumhurbaşkanı İsmet İnönü Arasındaki Adana Görüşmesi, (30-31 Ocak 1943)", 6'ncı Askeri Tarih Semineri I, İkinci Dünya Savaşı ve Türkiye 2022 Ekim 1997-İstanbul, Gnkur.Bsm., Ankara, 1998

Öztoprak, İzzet,’'Ikinci Dünya Savaşı Döneminde Adana Görüşmelerinin Askeri Yönü”, Altıncı Askeri Tarih Semineri Bildirileri I İkinci Dünya Harbi ve Türkiye 20-22 Ekim 1997-İstanbul, Gnkur.Bsm., Ankara,1998

TC. Dışişleri Bakanlığı, İkinci Dünya Savaşının Gizli Belgeleri, Sebat Matbaas1.,İstanbul, 1968

Uçarol, Rifat, "İkinci Dünya Savaş1 "Misak-1 Milli” ve Türkiye'nin Savaşa Girmemek için Direnişi”, Altıncı Askeri Tarih Semineri Bildirileri II İkinci Dünya Harbi ve Türkiye 20-22 Ekim 1997-İstanbul, Gnkur.Bsm., Ankara, 1999

Uslu, Nasuh, Türk-Amerikan İlişkileri, 21. Yüzyıl Yayınları, Ankara, 2000

William Hale, Çev.Petek Demir,Türk Dış Politikası 1774-2000, Mozaik Yay.,İstanbul, 2003

Yalçın, Durmuş-Avcı, Cemal, Türkiye Cumhuriyeti Tarihi II, Atatürk Araştırma Merkezi, Ankara, 2002

Yalçın, Mehmet Ali, İkinci Dünya Savaşının Gizli Belgeleri, MAY Yay., İstanbul,1968 